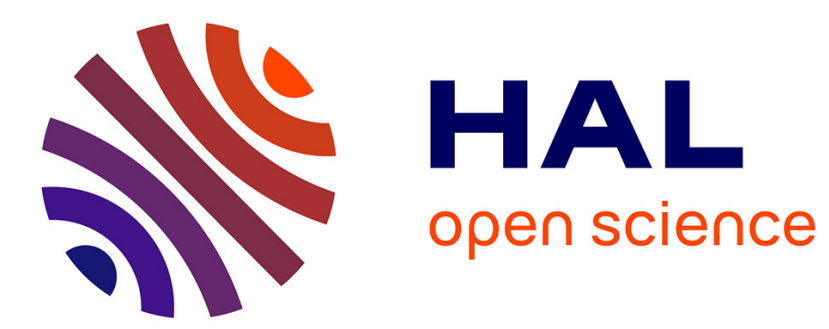

\title{
Property Rights and Labour Supply in Ethiopia
}

Kenneth Houngbedji

\section{To cite this version:}

Kenneth Houngbedji. Property Rights and Labour Supply in Ethiopia. 2018. halshs-01145827v2

\section{HAL Id: halshs-01145827 \\ https://shs.hal.science/halshs-01145827v2}

Preprint submitted on 16 Jan 2018

HAL is a multi-disciplinary open access archive for the deposit and dissemination of scientific research documents, whether they are published or not. The documents may come from teaching and research institutions in France or abroad, or from public or private research centers.
L'archive ouverte pluridisciplinaire HAL, est destinée au dépôt et à la diffusion de documents scientifiques de niveau recherche, publiés ou non, émanant des établissements d'enseignement et de recherche français ou étrangers, des laboratoires publics ou privés. 


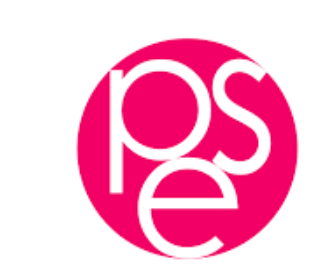

PARIS SCHOOL OF ECONOMICS
ECOLE D'ECONOMIEDE PARIS

WORKING PAPER N²015 - 12

\title{
Property Rights and Labour Supply in Ethiopia
}

\author{
Kenneth Houngbedji
}

JEL Codes: J2, 01, Q1

Keywords: Time allocation; Agricultural investment; Land administration; Property rights; Ethiopia

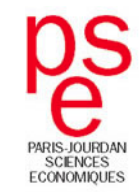




\title{
Property Rights and Labour Supply in Ethiopia ${ }^{\star}$
}

\author{
Kenneth Houngbedji ${ }^{\dagger}$ \\ Agence Française de Développement (AFD)
}

October, 2017

\begin{abstract}
In rural areas agricultural plots are seldom delineated and can be encroached upon by neighbours. Under these circumstances labour supply can be inefficiently distorted to safeguard the plots from encroachment. Using panel data, we study the variation of household labour supply following a land registration programme which has demarcated agricultural landholdings with cornerstones and has issued a documentary evidence of the household land rights. Our results indicate that after the registration of their landholdings, households with a land certificate have reduced total time allocated to farming activities with no impact on agricultural yields. The reduction in labour supply is primarily driven by a decrease of time allocated to the pre-planting season. This is consistent with qualitative evidence that plots under cultivation have no visible sign of demarcation during pre-planting and disputes arise as neighbouring landholders pushed the boundaries of their plots while ploughing. Following land registration, the cornerstones reduce the need for guarding parcels as they make encroachment easier to detect.
\end{abstract}

Keywords: Time allocation; Agricultural investment; Land administration; Property rights; Ethiopia.

JEL Classification: J2, O1, Q1.

*This work was supported by Région Île de France and funded under the grant "Policy Design and Evaluation Research in Developing Countries" of the Marie Curie Actions of the EU's Seventh Framework Programme (Contract Number: 608109). I am grateful to Klaus Deininger, Daniel Ali, and the Economic Department of Addis Ababa University and Gothenburg University for giving me access to the data set used; to Denis Cogneau, Karen Macours and Karine Marazyan for their invaluable support, suggestions and comments throughout the preparation of this paper; to Gani Aldashev, Jean-Marie Baland, Luc Behaghel, Guilhem Cassan, Alain de Janvry, Jeremie Gignoux, Michael Grimm, Renate Hartwig, Jean-Philippe Platteau, Harris Selod, Lara Tobin and the participants of the CRED Workshop, CSAE Conference in Oxford, Dial Conference in Paris, Development Seminar in Passau for helpful discussions and suggestions. I am thankful to anonymous reviewers for their careful reading and insightful comments and suggestions. Any remaining errors or omissions are mine.

${ }^{\dagger}$ Email: houngbedjik[at]afd.fr; Address: 5 rue Roland Barthes, 75012 Paris, France. 


\section{Introduction}

In developing countries, rural land rights are often undocumented and households allocate their scarce resources to safeguard against the risk of losing their land and forgo more productive opportunities (see, Besley and Ghatak, 2010; de Janvry et al., 2015; Goldstein and Udry, 2008). Since a plot left unattended is more likely to be expropriated, households have little incentive to migrate or rent-out their land to more productive farmers (de Janvry et al., 2015). Likewise, farmers will forgo opportunities to fallow their land - a significant low-cost investment which increases total land productivity in the long run - to maintain a continuous presence on their farm (Goldstein and Udry, 2008).

While the above-mentioned literature focusses on inefficiencies created by the medium to long term risk of losing a plot left unattended, we argue in this paper that households face also the ubiquitous risk of having their plots encroached upon by farmers with neighbouring plots. Since land size available for cultivation decreases when a plot is encroached upon, it is in the interest of households to safeguard their plot; especially during the seasons where their plots are most vulnerable to encroachment. Though households could in theory safeguard against encroachment by building fences around their plots, they would also benefit from a status-quo which allows them to increase the size of their plot by pushing its boundaries. Moreover, in some cases, fencing agricultural plots entails transaction costs which can exceed its private benefits. In this context, fencing is unattractive and households use other means to safeguard their plots. For instance, where opportunity costs of labour is low, household members can spend more time on their plots than required for production purposes. Since plots are left without visible sign of occupation during the pre-planting season, time allocated to safeguarding activities - guard labour - is more likely to be skewed during that season where risk of encroachment is higher.

The region of Amhara in Ethiopia offers two features which makes it an ideal environment to test the relationship between time allocated to farming activities and land tenure security. First, individual households in Amhara have very little incentive to delineate their landholdings. Following a radical reform in 1975, which nationalized all land in Ethiopia, every person was entitled to a piece of land conditional on self-cultivation and permanent physical presence in a location (Devereux and Guenther, 2007). To enforce those rules, peasant associations (PA) were created at the village - kebele - level and carried out periodic land redistribution 
campaigns to accommodate demand from landless households and to maintain an egalitarian land distribution. As a result of these campaigns, household landholdings are fragmented and scattered within the villages. Though boundary disputes were reported as the most common source of land conflicts for landholders (see Belay, 2010), the threat of land redistribution and land fragmentation make fencing an unattractive solution. Moreover, a landholder who wishes to fence his plots is likely to bear the cost of coordinating with holders of neighbouring plots and the PA officials.

Second, the region of Amhara created the Environmental Protection Land Use and Administration Authority (EPLAUA) in 2000 to improve tenure security and agricultural productivity. As part of its mandate EPLAUA carried out a state-wide land registration programme to demarcate and register the agricultural landholdings and provide agricultural households with a documentary evidence of their land rights enforceable by the State (Tegnäs et al., 2009). As the land registration programme proceeds to the physical demarcation of plots with cornerstones it renders encroachment easier to detect on a demarcated land. The cornerstones should also discourage would-be encroacher from extending the limits of their parcels and should reduce time encroachers and encroachees would spend on their plots. Hence, we should expect a stable equilibrium of reduction of time previously allocated to agricultural activities for most households.

To study how time allocated to agricultural activities varies with land registration, we use panel data of households collected in Amhara before and after the land registration activities. For practical reasons, the land registration program proceeded from one kebele to the other until all the plots in Amhara were registered. Consequently, the plots located in different kebeles were not registered simultaneously. When the registration activities reach a kebele and all the plots have been demarcated, farmers were invited to a public gathering to discuss and settle issues raised by the registration activities. After that, the results of the demarcation activities were sent to district officials who issue the land certificates and send them to the households. Given the staggered implementation of the programme and the administrative procedures pending the issuance of the land certificates, the timing of the receipt of the land certificates is to a large extent exogenous to households characteristics. This variation allows us to estimate the effect of the land registration program for the households that received their land certificate just on time to decide the amount of time to allocate to farming activities of the next agricultural year. 
To estimate how labour supply responds to land registration, we use household characteristics at the baseline to estimate the probability that each household receives a land certificate on time for the agricultural season. Then, we compare the average change of labour supply before and after the receipt of land certificate for the households that receive their land certificates ahead the treated households - to the average change of time allocated to farming activities by households that did not receive their certificates on time - the untreated households. We adjust for the selection bias by weighting each household proportionally to its probability to receive its land certificate on time. The validity of this approach rests on the assumption that change in time allocated to agricultural activities evolve similarly across treated and untreated households in absence of the issuance of the land registration programme. Since the households of our study are observed three times before the issuance of the land certificate, we show tests suggesting no change and labour supply between treated households and their counterfactual prior to the issuance of the land certificates.

Our results show that, following completion of the land demarcation activities and issuance of the land certificates, time allocated to farming activities decreased by 8 to 14 person-days for the households that had received their land certificates on time. This represents a decrease of 8.3 to $13.5 \%$ of labour supply. We also find that most of the reduction in labour supply came from a decrease of time allocated to pre-planting activities during which the parcels were more vulnerable to encroachment. Consequently, the decrease in time allocated to farm activities was not accompanied with a decrease of agricultural output nor compensated with increased used of fertiliser or improved seed. Further analysis reveals that the decrease of time allocated to farming activities was stronger for households that had several landholdings. This is consistent with the fact that those households had to guard several plots at once. These findings lend support to anecdotal evidence recorded during the land registration activities showing that "marking the boundaries with white stones was [...] advantageous for weaker landholders (women, elderly, chronically ill) as other landholders constantly push the boundaries of their holding during ploughing" (see Adenew and Abdi, 2005, p. 15)

This study contributes to the literature on endogenous property rights which shows that investments on a piece of land strengthens land use rights (Besley, 1995; Besley and Ghatak, 2010; Brasselle et al., 2002). Previous studies illustrate that principle in various ways. Most notably, there is evidence that land tenure security is strengthen through physical investments made on the plots (Brasselle et al., 2002; Deininger and Jin, 2006), social and political power 
of the landholder (Goldstein and Udry, 2008), and active land use of the plots (de Janvry et al., 2015). Regarding the link between land tenure security and time allocation, Field (2007) studies the effect of a land formalisation programme on labour supply of households living in informal urban neighbourhoods of Peru and finds that "the net effect of property titling is a combination of an increase in total labour force hours and a reallocation of work hours from inside the home to the outside labour market" (see Field, 2007, p. 1563). A key difference with Field (2007) is that urban squatters in Peru were defending their homesteads from eviction whereas, in Amhara, the agricultural plots are income-generating assets. Moreover, we show that time allocated to farming activities was most likely related to the absence of cornerstones and fear of encroachment during pre-planting season.

The rest of the paper is organized as follows. In section 2 we give a background of access to land in Ethiopia and describe the land registration programme in Amhara. Section 3 considers a theoretical framework to explore more formally the relationship between risk of land loss through encroachment and time allocation to farming activities. In section 4 the emphasis switches from theory to practice. We describe the data used to test the main predictions of the model and discuss the strategy used to causally identify the effects of land registration on time allocation. Section 5 presents the econometric framework and Section 6 discusses the results. Section 7 offers concluding observations.

\section{Background}

\subsection{Access to Land in Ethiopia}

Located in the Horn of Africa, Ethiopia was once an empire. All land was owned by the crown and citizens could obtain the right either to use a plot and have full ownership of the product of their labour or collect taxes from those who lived at a given location. ${ }^{1}$ Following the demise of the Imperial regime and the promulgation of a land reform in 1975, all land was nationalized and pre-existing land rights were abolished. Every Ethiopian became entitled to the use of land and had full ownership of the product of her labour, creativity and capital but land could neither be inherited, rented-out, sold or mortgaged (Adal, 2002; Crewett and Korf, 2008; Holden and Yohannes, 2002). Tenants and freeholders kept the land they were cultivating at

\footnotetext{
${ }^{1}$ The land use right was hereditary and peasants could claim a share of land based on their relationship to an ancestral first landholder. The right to collect taxes was granted to the members of the ruling elite or religious institutions as a reward (Adal, 2002; Bruce et al., 1994; Tegegne, 2009).
} 
the time of the reform and the elite was allowed to keep some of their land if they were willing to cultivate it themselves. Tenure security was therefore contingent on land cultivation. ${ }^{2}$

In the aftermath of the reform, the country went through several conflicts and recurrent droughts. A growing number of young adults, returning soldiers, settlers, refugees and other displaced populations were in quest of land and periodic land re-distributions were carried out to accommodate the need of every claimant (Holden and Yohannes, 2002; Rahmato, 1994). Besides, many households were engaged in sharecropping, cash rental contracts, sales and other illegal arrangements to meet the increasing demand for land (Bruce et al., 1994). As tenure insecurity increased and households resorted to their political ties to safeguard their claims to land, peasant associations were accused of favouritism towards their relatives and friends and pressure for a new reform rose (Adal, 2002).

Formed in 1995 and passed in 1997 respectively, the Ethiopian Constitution and the Federal Land Administration and Use Proclamation have given legal recognition to several land practices that were previously "illegal" in an attempt to allay farmers' fear of land-loss (Crewett et al., 2008; Rahmato, 1994). However, the threat of land redistribution remained present and households engaged in "desperate" mitigating practices to keep their landholdings. Ege (1997) reports that some peasants took back tenancy land rented out in order not to lose it but were then not able to cultivate it properly themselves. Richer households tried to strengthen their claims by building a house on the land and peasants who had mortgaged their land started to reclaim it while those who had lent money were worried of losing both their money and the collateral.

Despite the shortcomings in addressing tenure security, the Constitution and the Federal Land Use Law paved the way for the land registration programme. While land ownership remains vested in the state, a land registration process demarcates the landholdings and provides legal recognition of the land use rights. The regional government is liable for protecting and enforcing the rights of each land certificate holder which should decrease the likelihood of new land redistributions by local peasant associations. In facts, the registration process may reduce the influence of kebele officials. This aspect has created some friction and power struggle which may undermine the security value of a land certificate. For instance, some kebele officials have "stated that if someone left their land for a period of more than two years, regardless of whether they held

\footnotetext{
${ }^{2}$ The maximum landholding per individual was capped at $10 \mathrm{ha}$, land was distributed according to household size and households were allocated plots of different quality in different locations.
} 
a certificate, they would take the land and distribute it to someone else" (see ARD, 2004, p. 12).

Tigray was the first region to start a rural land registration initiative in 1998. The region of Amhara where the data used in this paper has been collected started a land registration programme in 2002. Other regions such as Oromiya and the Southern Nations and Nationalities (SNNR) started to register landholdings in 2004.

\subsection{Land Registration in Amhara}

Amhara is a large and highly fertile agricultural region of Ethiopia known for its potential for irrigation, hydro-power and commercial fisheries. The region had many episodes of land redistribution which contributed to a high degree of land fragmentation. The last redistribution exercise was carried out from 1997 to 1998. Benin and Pender (2001) find that the land redistribution of 1997-98 increased land productivity by giving access to land to farmers who were more able to use fertilizer. Benin and Pender, however, do not find "much effect of land recent land redistribution or expectations of future redistribution on land improvement and management" (see, Benin and Pender, 2001, p. 555).
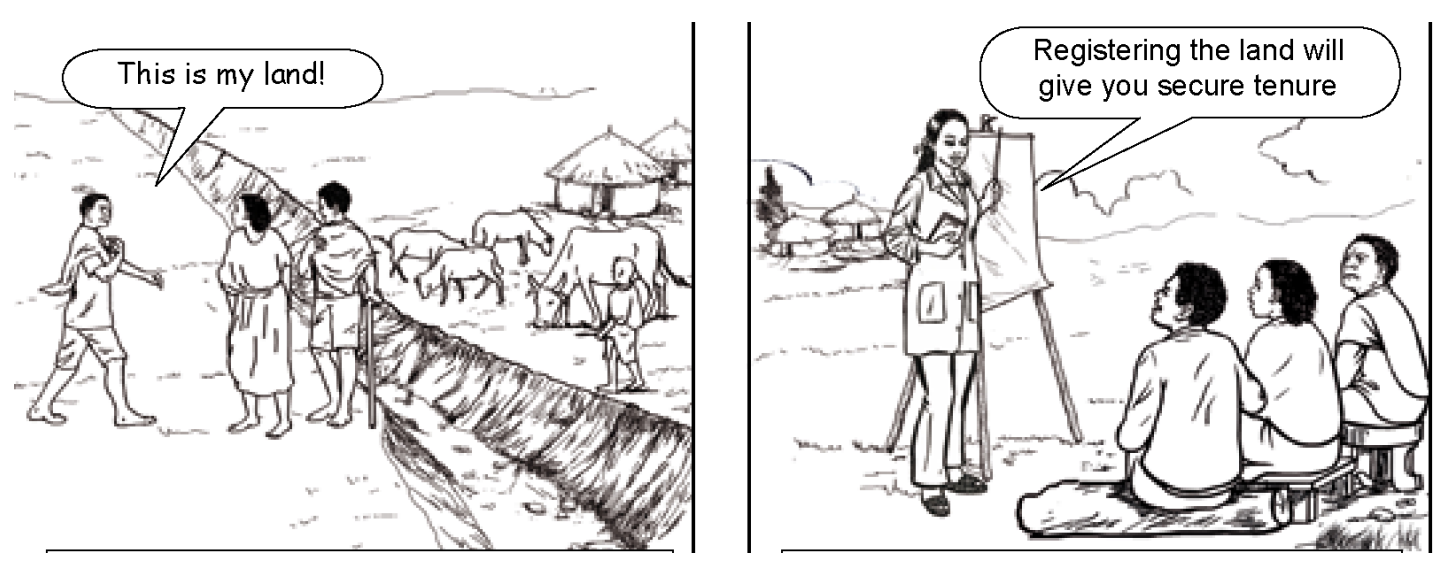

Figure 1: Information Campaign.

Source: This is an excerpt from SARDP (2010).

To improve tenure security, reduce land degradation and encourage investment in soil and water conservation infrastructure, the Government of Amhara created the Environmental Protection Land Use and Administration Authority (EPLAUA) in 2000. In 2002, with the support of the Swedish International Development Cooperation Agency (Sida), a land registration programme was launched by EPLAUA. It aimed at conducting a cadastral survey which includes land disputes resolution, demarcates each plot with painted stones and issues a certificate list- 
ing the landholdings of the households. ${ }^{3}$ After a pilot phase from July 2002 to June 2003, the land registration programme was expanded to the whole region and proceeded from one $k e-$ bele to another to inform farmers about the advantages of holding a land certificate and invited them to apply for their holdings to be demarcated (see Figure 1 and Figure 2). The records of the 1997 land redistribution were used as a benchmark and each claim was verified by a democratically elected land administration committee (LAC) in the kebele. Therefore, land rights acquired after 1997 which had not been authorized were considered illegal by EPLAUA and were neither certified, nor registered. Successful claimants were issued a "temporary certificate". Their
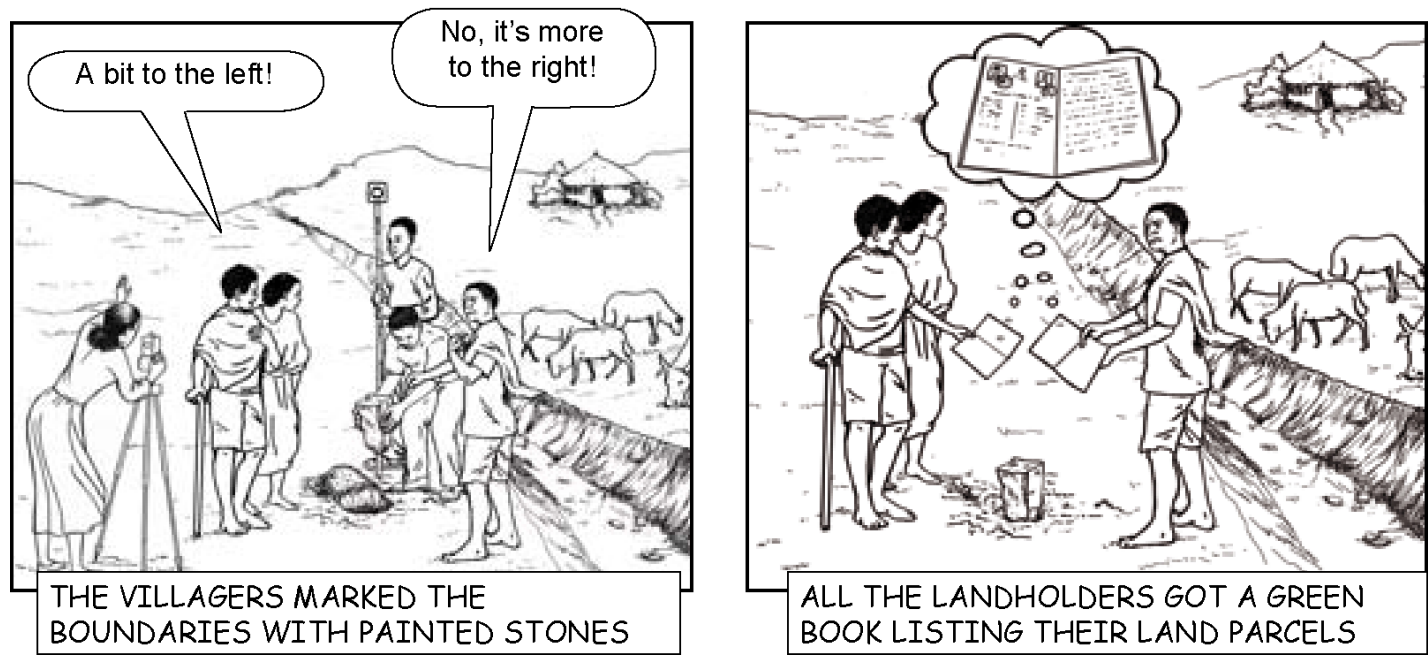

Figure 2: Land Demarcation Activities.

Source: This is an excerpt from SARDP (2010).

landholdings were publicly debated for one month in order to verify whether a third party will claim the land that is being registered. In case of agreement and after corrections were made following the public hearing, the "primary certificate" which legally recognizes the rightful users of the land was issued (SARDP, 2010). ${ }^{4}$

By December 2009, 4.9 million landholdings had been registered and 890,000 households had received their certificates. ${ }^{5}$ Studying the impact of the land registration programme, Bezabih

\footnotetext{
${ }^{3}$ As part of its effort to reduce poverty, the Sida-Amhara Rural Development Programme (SARDP) seeks to improve food security of the rural population in 30 districts of the East Gojjam and South Wollo zones. The SARDP covers various activities including land registration, economic diversification, infrastructure development and social services, decentralization and taking action on issues such as gender and HIV-AIDS prevention.

${ }^{4}$ The primary certificate records the names and addresses of the landholder (both husband and wife if the land is held jointly), their photographs, the names of their family members, a list of each demarcated landholding, the estimated area, the land use and the names of the neighbouring landholders.

${ }^{5}$ There is no official figure about the number of households that failed to register their land. Comparing the housing and population census to the output of the land registration programme, Tegnäs et al. (2009) estimate that $5 \%$ of landholdings were likely considered as illegal and not registered. Concerns related to this will be addressed when presenting the identification strategy of the paper.
} 
et al. (2011) find that the formalization of land rights has increased trust in formal institutions of the regional and the federal governments but had no marked impact on trust towards local institutions, other people and trade partners. ${ }^{6}$ A field survey reveals that $98 \%$ of farmers who received a certificate have reported that "they now have more secure land tenure or are more secure in the knowledge that they will be compensated if their land is expropriated" (see Tegnäs et al., 2009, p. 31). These comments are in line with the findings of Deininger et al. (2011) who compare households with and without land certificates before and after the issuance of land certificates. Deininger et al. (2011) find that the issuance of land certificates reduced the fear of land loss by 10 percentage points, increased the propensity to rent out land by 13 percentage points and increased the propensity to invest in soil and water conservation measures (swc) by 20 percentage points.

As land traditionally belongs to the tiller, the land registration programme in Amhara is likely to also affect the amount of time allocated to agricultural activities for two main reasons. First, as in Mexico where land security was linked to active land use, some households may be freed from cultivating their land themselves in order to safeguard their land rights (de Janvry et al., 2015). This is based on the assumption that, by reducing the perceived likelihood of future land redistribution, the land registration program will facilitate the reallocation of household labour supply to non-farm activities. This mechanism, however, is not likely since kebele officials are still threatening to reallocate land which are not self cultivated (ARD, 2004). Hence, in the short run, households may still fear losing the parcels they do not actively cultivate themselves. Moreover, the reallocation of labour supply outside agriculture will likely be gradual as households discover opportunities outside agriculture. Second, Adenew and Abdi (2005) and Belay (2010) report that disputes over land boundaries are common in Amhara and neighbours constantly push the boundaries of their landholdings during ploughing. Since the implantation of cornerstones clarifies the limits of the parcels and makes encroachment easier to detect, the land registration activities may have a more immediate effect on labour supply by relaxing the need for guarding activities. This could explain how households with land certificates were able to allocate time to building/repairing soil and water conservation infrastructures on their landholding as reported by Deininger et al. (2011). To conclude, in the sort run, we expect that the registration activities will freed time previously allocated to safeguarding land from

\footnotetext{
${ }^{6}$ More precisely, Bezabih et al. (2011) estimate that the issuance of a land certificate is associated with a $14.2 \%$ and $16.4 \%$ increase in the likelihood of perceiving the regional and the federal governments respectively as completely trustworthy.
} 
encroachment and in the longer run they will facilitate investment on in off-farm activities and increase household welfare.

\section{Analytical Framework}

In this section we develop a model to conceptualize the relationship between fear of land loss and time allocation. The model pursues a more limited objective than the general theory of time allocation of Besley and Ghatak (2010) from which it draws strongly. While the model is not fully representative of all the constraints faced by agricultural households, we find it useful to derive falsifiable predictions regarding labour supply when households allocate their time endowment to safeguard their landholdings.

\subsection{Model}

Consider a risk neutral agricultural household with $\bar{k}$ hectares of land endowment and $\bar{e}$ units of time endowment. Land distribution is egalitarian and the household can neither exchange, rent out or mortgage its land endowment. As in the slogan "land to the tiller" the household has an usufruct right of the product of its labour and access to a field which is cultivated is never lost. Farm production, $q\left(\bar{k}, e_{1}\right)$, varies with land endowment $\bar{k}$ and productive effort $e_{1}$ ( where $0<e_{1} \leq \bar{e}$ ) and we abstract from the situation where the household does not cultivate its plots. The household consumes the produce of its farming activity and derives utility $u(x, l)=x+l$ from its level of consumption $x$ and the amount of time allocated to activities other than farming activities. We call those activities "leisure" or $l$.

Plots left without visible sign of occupation over a certain period (two years according to ARD (2004)) is sought after by the peasants associations and reallocated to landless households (Adal, 2002; Ali et al., 2007; Crewett and Korf, 2008; Holden and Yohannes, 2002). Similarly, land left unguarded or without visible signs of occupation over short periods can be encroached upon by neighbouring households (Adenew and Abdi, 2005; Belay, 2010). When a plot is left without visible sign of occupation, e.g. during ploughing and before planting or after harvest or during fallow, the household allocates $e_{2}$ units of its time endowment to protect it from encroachment.

More formally, if the probability of land loss through encroachment for a plot left unguarded is $\tau$ and $s\left(\bar{k}, e_{2}\right)$ is the mitigating effect of allocating $e_{2}$ amount of time to guarding activities then 
a household can safeguard the integrity of its landholding with a probability, $1-\tau+s\left(\bar{k}, e_{2}\right)$. The tenure security production function, $s\left(\bar{k}, e_{2}\right)$, is a concave function twice differentiable that increases with time allocated to guarding activities and decreases with the size of land endowment. Safeguarding a large plot - or several fragmented plots - requires more effort and risk of land loss through encroachment decreases with the level of guard labour exerted. ${ }^{7}$

Given that land belongs to the tiller, there is limited willingness to undermine claims to land by hiring workers or renting it out. The household allocates its time endowment to solve the problem below:

$$
\max _{e_{1}, e_{2}}\left(1-\tau+s\left(\bar{k}, e_{2}\right)\right) \times q\left(\bar{k}, e_{1}\right)+\left(\bar{e}-e_{1}-e_{2}\right)
$$

The optimal conditions for an interior solution are

$$
\begin{aligned}
& 0=\left(1-\tau+s\left(\bar{k}, e_{2}\right)\right) \times q_{e}-1 \\
& 0=s_{e} \times q\left(\bar{k}, e_{1}\right)-1
\end{aligned}
$$

where $q_{e} \equiv \frac{\partial q}{\partial e_{1}}$ is the marginal product of effort, $s_{e} \equiv \frac{\partial s}{\partial e_{2}}$ is the marginal tenure security provided by each additional unit of guard labour. ${ }^{8}$

The equations (2a)-(2b) describe the equilibrium conditions for allocating time between production, guarding and leisure. Equation (2a) states that, when it exists, the optimal level of productive effort equates the expected marginal product of effort and its cost, i.e. the marginal utility of leisure. Likewise, equation (2b) shows that time is allocated to guarding activities until the share of production saved from encroachment equates forgone marginal utility of leisure lost while guarding the plots. To explore the implications of equations (2a) and (2b), we make some simplifications to derive analytical solutions. Namely, we assume that productive effort yields a stochastic output $A \bar{k}$ with probability $\gamma e_{1}$ and nothing with probability $1-\gamma e_{1}$. The

\footnotetext{
${ }^{7}$ In the context of Amhara, the households endowed with land of poor quality, e.g. sloped farm plots, were compensated by the peasant association with larger land endowment (see e.g., Ege, 1997). Land size was therefore, less of a sign of wealth. Besides, land endowment is often fragmented across several non-contiguous land parcels because peasant associations had to level down existing holdings and parcel up and distribute grazing land to accommodate the increasing population (Rahmato, 2004).

${ }^{8}$ In theory there could be corner solutions where households cultivate their farms to signal land use when land should actually be left fallow (i.e $e_{1}=0$ and $e_{2}>0$ ). This would be the case when farming is less desirable than other activities. That prediction has been tested: In Ghana, Goldstein and Udry (2008) find that households with political power enjoy higher tenure security and are more likely to leave their plots fallow than their peers without political leverage and hence lower tenure security. In Mexico, de Janvry et al. (2015) find that de-linking land use from land rights has freed household labour that was otherwise used to signal plot use. In Amhara, it is worth noting that households' livelihood in Amhara depend on agriculture. The main crop cultivated is teff which is used as staple food $-86 \%$ of the households in our sample have cultivated teff at baseline. Hence, corner solutions where plots are cultivated only to signal land use would be rare.
} 
expected output of the farmer is therefore:

$$
q\left(\bar{k}, e_{1}\right)=A \bar{k} \gamma e_{1}
$$

where $A$ is the total productivity of land and $\gamma$ is a positive parameter that characterizes labour productivity such that $0 \leq \gamma \times e_{1} \leq 1$. The tenure security production function is

$$
s\left(\bar{k}, e_{2}\right)=\eta \times \frac{e_{2}}{\bar{k}}
$$

where $\eta$ is a positive parameter that determines the effectiveness of time allocated to guarding activities such that $0 \leq 1-\tau+\eta \times \frac{e_{2}}{\bar{k}} \leq 1$.

\subsection{Predictions}

Using the functional form assumptions (3) and (4), solving the equations (2a)-(2b) yields:

$$
e_{1}^{\star}=\frac{1}{A \eta \gamma} \quad \text { and } \quad e_{2}^{\star}=\frac{1-A \bar{k} \gamma(1-\tau)}{A \eta \gamma} .
$$

Taking the derivatives of Equation (5) with respect to the expropriation risk, $\tau$, gives

$$
\frac{\partial e_{1}^{\star}}{\partial \tau}=0 \quad \text { and } \quad \frac{\partial e_{2}^{\star}}{\partial \tau}=\frac{\bar{k}}{\eta}>0
$$

Hence, a reduction of the expropriation rate has no impact on productive labour but reduces the amount of time allocated to guarding activities. Moreover, guard labour decreases further for household which received larger landholding in compensation for poor soil quality.

In most cases, however, it is impossible to disentangle between guard and productive labour.

Only total effort allocated to farming activities, $e^{\star}=e_{1}^{\star}+e_{2}^{\star}$ is observed. Given that one can write $\frac{\partial e^{\star}}{\partial \tau}=\frac{\partial e_{1}^{\star}}{\partial \tau}+\frac{\partial e_{2}^{\star}}{\partial \tau}$ we derive the following predictions:

H 1. A reduction of the expropriation rate decreases total effort allocated to farming activities.

H 2. A reduction of the expropriation rate has a bigger impact on total effort allocated to farming activities on larger landholdings.

To summarize, the model shows that land registration, through land disputes resolution and formal land demarcation with issuance of land certificates, sets benchmarks to detect and re- 
solve future land disputes and frees landholders from allocating time to guarding activities. Since a larger landholding size, which can also be composed of several small non-contiguous plots scattered across the village increases guarding effort, the land certification programme should have a larger impact on households with either a large land endowment or several land parcels.

\section{Data}

\subsection{Summary Statistics}

To study the relationship between the land registration programme and time allocation empirically, we use a panel survey covering 716 rural households, randomly selected across six kebeles of the zone East Gojjam in Amhara. ${ }^{9}$ The households were interviewed four times: SeptemberOctober 1999, July-August 2002, September-November 2004, and July-August 2007. Most of them have been successfully followed over time and attrition appears uncorrelated with households' characteristics (see Table A-1 and TableA-2). The analysis focuses on the 669 households present in all the four rounds of the survey and exploits information on households' plots and agricultural activities during the latest main rainy season - meher - at the time of the survey. ${ }^{10}$

Given the egalitarian principle behind the 1975 land reform and the 1997 land redistribution in Amhara, the distribution of the landholding size across households in the sample is concentrated. The average landholding size held by household in 1999, i.e. about one year after the latest land redistribution, is estimated at 0.35 ha per adult equivalent unit (aeu) and $80 \%$ of the households have between 0.15 and 0.6 ha per aeu. ${ }^{11}$ Variation of land endowment is partly explained by the variation in soil quality since households with sloped land are compensated with a larger land endowment (Holden and Yohannes, 2002). Land endowment is also extremely fragmented as the average household has slightly more than five disjunct landholdings. Most of the households have at least one ox and cultivate teff, the staple crop in Ethiopia. Other crops cultivated are sorghum, pulses, oilseeds and vegetables. The households

\footnotetext{
${ }^{9}$ The original data set covers seven kebeles. However, the kebele Adishena Gulit was included in the panel only in the third round and hence information for households of this kebele is missing for the first two rounds. Though Addissena Gulit is included in the analysis provided by Deininger et al. (2011), we have excluded it to preserve the balanced panel dimension of the data set.

${ }^{10}$ The meher usually lasts from June to September while the corresponding agricultural season covers a period of approximately 9 months from June to February of the following year. Hence, information collected in 1999, 2002, 2004 and 2007 correspond respectively to agricultural activities of the meher 1998-99, 2001-02, 2003-04 and $2006-07$.

${ }^{11}$ The adult equivalent unit is created to account for the household structure. It attributes different sizes to household with respect to age and gender of its members as follows: Male 15 years or older $=1$, female 15 years or older $=0.8$, male or female 14 years or under $=0.5$.
} 
Table 1: Descriptive Statistics of Households in 1999.

\begin{tabular}{|c|c|c|c|c|c|c|}
\hline Variables & Obs & Min & Mean & Median & iqr & Max \\
\hline \multicolumn{7}{|l|}{ Panel A: Household Characteristics } \\
\hline Female headed $\mathrm{hh}^{\dagger}$ & 669 & 0 & 0.11 & 0 & 0 & 1 \\
\hline Age of hh head (yrs) & 669 & 17 & 44.6 & 45 & 24 & 90 \\
\hline $\mathrm{HH}$ head is literate ${ }^{\dagger}$ & 669 & 0 & 0.42 & 0 & 1 & 1 \\
\hline Household size & 669 & 1 & 5.21 & 5 & 3 & 11 \\
\hline Number of oxen & 669 & 0 & 1.51 & 1 & 1 & 7 \\
\hline $\mathrm{HH}_{\text {main }}$ activity: farming ${ }^{\dagger}$ & 669 & 0 & 0.88 & 1 & 0 & 1 \\
\hline Homestead with iron sheets roof ${ }^{\dagger}$ & 669 & 0 & 0.57 & 1 & 1 & 1 \\
\hline Distance homestead-town (mins) & 669 & 0 & 67.8 & 60 & 50 & 240 \\
\hline Number of landholdings & 669 & 1 & 5.52 & 5 & 3 & 17 \\
\hline Total land size (ha) & 669 & 0 & 1.38 & 1.25 & 1.05 & 3.79 \\
\hline Land size per aeu (ha) & 669 & 0 & 0.35 & 0.30 & 0.22 & 2.09 \\
\hline Land size allocated to teff (ha) & 669 & 0 & 0.58 & 0.50 & 0.65 & 3.03 \\
\hline Livestock (\$) & 669 & 0 & 932.1 & 772 & 968 & 5343 \\
\hline Off-farm income (\$) & 669 & 0 & 69.9 & 0 & 90 & 998 \\
\hline
\end{tabular}

Panel B: Land tenure security over the next 5 years

$\begin{array}{lllllll}\text { HH expects change of land size }^{\dagger} & 669 & 0 & 0.76 & 1 & 0 & 1 \\ \text { - HH expects land gain } & 669 & 0 & 0.55 & 1 & 1 & 1 \\ \text { - HH expects land loss } & 669 & 0 & 0.21 & 0 & 0 & 1\end{array}$

Panel C: Land use and time allocation

\begin{tabular}{lllrrrr} 
Household labour & 669 & 0 & 115.3 & 93 & 111 & 601 \\
- Children & 669 & 0 & 5.58 & 0 & 4 & 82 \\
- Adults & 669 & 0 & 109.8 & 90.5 & 104.5 & 529 \\
Debo workers & 669 & 0 & 7.15 & 3 & 11 & 121.7 \\
Hired workers & 669 & 0 & 0.71 & 0 & 0 & 60.5 \\
Land size plough (ha) & 669 & 0 & 1.22 & 1.13 & 1.12 & 5.23 \\
\hline \hline
\end{tabular}

${ }^{\dagger}$ Indicates dummy variables.

own on average two oxen and have other cattle including calves. The value of livestock held by households in 1999 was estimated at $\$ 932 .{ }^{12}$ The revenues from off-farm employment were estimated at \$ 30 for the period; around 14\% of the GDP per capita (see Table 1).

To measure land tenure insecurity, households were asked whether they expect an increase or a reduction of their landholding size over the next five years. In 1999, 76\% of the households surveyed expressed such concerns for the period 1999-2004: 21\% expected a land loss and $55 \%$ expected a land gain through the reallocation by peasant associations. The proportion of households in our panel expecting a land loss remained stable around 21\% between 1999 and 2004 and was estimated at $26 \%$ in 2007 . Correlating household characteristics to fear of land loss, it appears that fear of land loss is mostly associated with larger land endowments

\footnotetext{
${ }^{12}$ Prices are expressed in purchasing power parity (PPP) at constant 2005 international \$. The livestock held on average by the households in 1999 was twice the per capita GDP of Ethiopia at that time.
} 
(see Table A-3). With the start of the land registration activities in 2004, fear of land loss was associated with households with older or literate household heads and relatively wealthier households. ${ }^{13}$ This confirms the prevailing sense that peasant associations reallocate land to younger landless households to accommodate population pressure. Since a sizeable proportion of the households is still concerned about the loss of land between 2007 and 2011, it seems that the land registration programme did not succeed in eliminating threat of land reallocation by the peasant associations.

Time allocated to farm activities is measured in person-days at the household level by addingup the number days spent by household members on the plots cultivated during the last meher. For the meher of 1998-99 household adult members spent on average 110 person-days on their plots. Since the meher season covers approximately 270 days, a household with one adult member would then, on average, work on his fields every other day. Other sources of labour used by households include a traditional form of voluntary collective work that renders labour upon need to fellow neighbours, debo, as well as hired workers. ${ }^{14}$

\subsection{Implementation of the Programme}

The land registration programme in Amhara proceeded from one kebele to another and the kebeles covered by this study have started the land demarcation activities at different moments. At the time of the first two rounds of the survey, the registration process had not started in any of the kebeles of the sample. By the time of the third round, land registration activities were ongoing in three kebeles. At the fourth round, the programme has reached all the kebeles and the issuance of the land certificates had started in five kebeles (see Figure 3).

In June 2006, at the beginning of the meher of $2006-07,27 \%$ of the households completed the land registration process and received their land certificates - the treated households - while the others - the untreated households - had either a temporary or no certificate (see Table A-4). ${ }^{15}$ At the time of the fourth round, in August 2007, the treated households have had their land certificates for an average period of 16 months and their plots have been measured using tape

\footnotetext{
${ }^{13}$ Having iron corrugated sheets as rooftops often equates an external sign of wealth.

${ }^{14}$ In 1999, 66\% used debo workers and 20\% hired workers to farm their land. The type of labour used varies across agricultural tasks. Household members are involved in every task from pre-planting, planting, weeding, harvesting to threshing. Debo labour is mainly used to provide additional manpower during threshing and harvesting whereas paid workers are used for skilled tasks like weeding and also during harvesting.

${ }^{15}$ In August 2007, 52\% of the households had their land certificates. We show later that only few household characteristics are correlated with receiving a land certificate on time for the agricultural season. Hence only the staggered pattern of the programme into the kebeles determines the households that get their land demarcated first and receive their certificates earlier.
} 


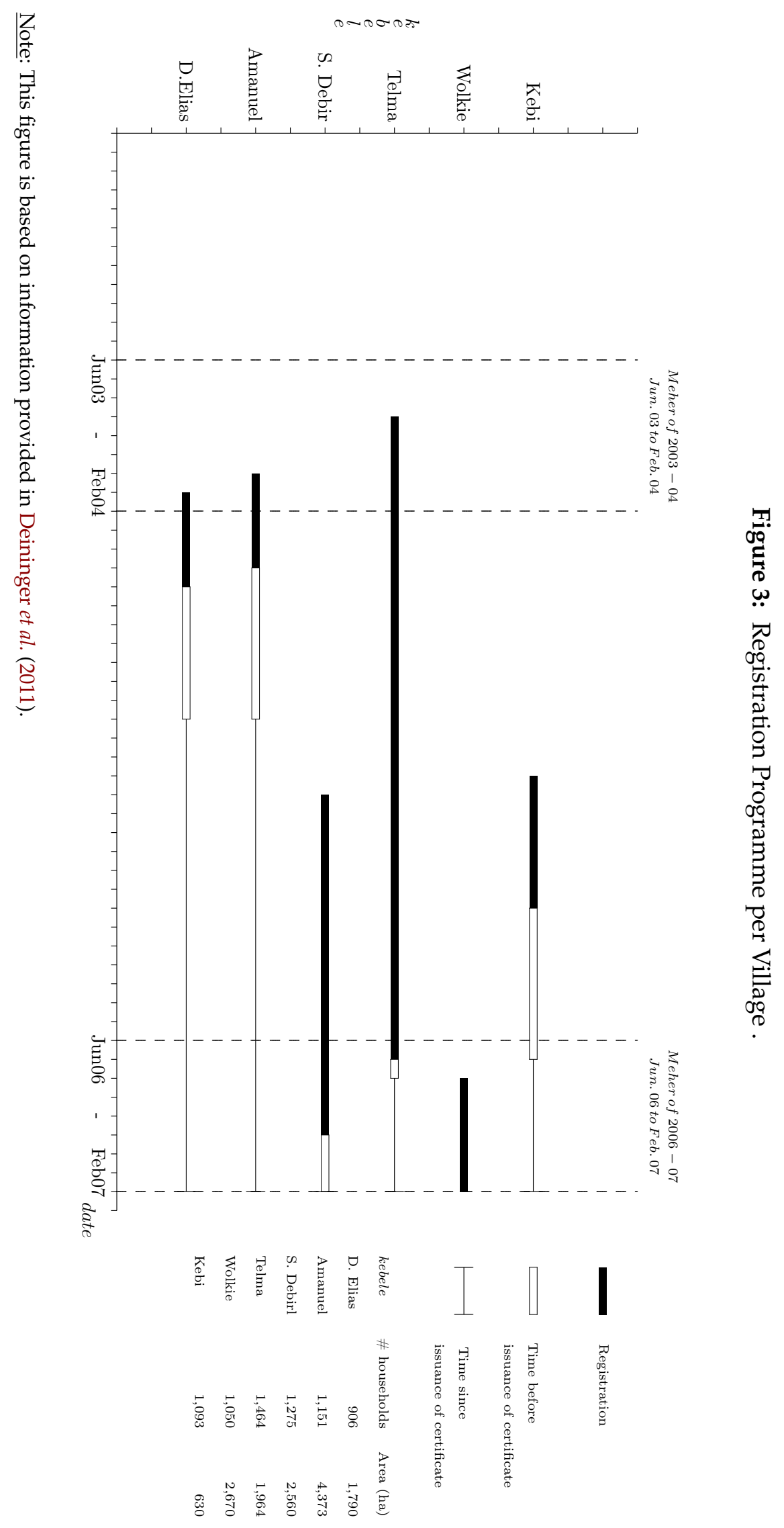


and rope in the presence of the landholders of neighbouring plots. In comparison, though some of the untreated households without a land certificate in June 2006 would receive one by August 2007, most landholdings were not measured.

If households are convinced that their landholding is safe after formal registration then those holding a primary land certificate in June 2006 would be more likely to substitute their land certificate with other means used to safeguard their rights. Therefore, as predicted earlier in Section 3, time allocated to farming activities to prevent encroachment from neighbours should decrease during the meher of 2006-07 with respect to the level observed in 1998-99 in the treated households.

However, comparing the variation of labour supply over time across households with and without a land certificate will fail to identify the effect of the land registration programme if both groups differ in characteristics that affect labour supply dynamics. Table 2 shows that dynamics of the time allocated to farming activities differ between treated and untreated households in the absence of the land registration programme. Labour supply has decreased between 1999 and 2002 for treated households and has remained almost constant for untreated households. Treated households are also larger, have more oxen, live closer to the district town and allocate more time to farming activities. These factors are correlated to the issuance of the land certificates and confound the effect of land registration on land and time use. Besides, the information on time use collected does not differentiate between guard labour and production effort; which can be differently affected by an increase of tenure security. ${ }^{16}$ To parse out those confounding factors we resort to the potential outcomes framework developed of Rubin (1974) and make some simplifying but falsifiable hypothesis which we describe in the next section.

\section{Econometrics}

Since the unconditional assumption of parallel trends is not likely to hold, we compare the change of time allocated to farming activities between 1999 and 2007 by treated and untreated households depending on their probability to get their certificate on time for the meher 2006-07. If the effect of the unobservable differences between treated and untreated households on time

\footnotetext{
${ }^{16}$ The measurement issue is a particular concern if the issuance of land certificate increases productive effort. Though not considered in the theoretical framework, a household with a land certificate can also either invest in more productive technology or rent out his plot. In this case the productive effort increases with a reduction of the probability of land loss through encroachment. In this case formal land demarcation can be associated with an increase of household labour supply during the 2006-07 agricultural season. This scenario is discussed later when interpreting the results.
} 
Table 2: Households Characteristics in 1999 and 2002 by Treatment Status.

\begin{tabular}{|c|c|c|c|c|c|c|c|}
\hline \multirow{2}{*}{ Variables } & \multicolumn{3}{|c|}{ Treated } & \multicolumn{3}{|c|}{ Untreated } & \multirow{2}{*}{$\begin{array}{l}\text { diff. } \\
(1)-(2)\end{array}$} \\
\hline & 1999 & 2002 & diff.(1) & 1999 & 2002 & diff.(2) & \\
\hline \multirow[t]{2}{*}{ Female headed $\mathrm{hh}^{\dagger}$} & 0.13 & 0.11 & -0.03 & 0.11 & 0.11 & 0.00 & $-0.03^{*}$ \\
\hline & $(0.03)$ & $(0.02)$ & $(0.03)$ & $(0.01)$ & $(0.01)$ & $(0.02)$ & $(0.02)$ \\
\hline \multirow[t]{2}{*}{ Age of hh head (yrs) } & 45.70 & 48.16 & 2.45 & 44.15 & 45.69 & 1.54 & $0.91^{* *}$ \\
\hline & $(1.08)$ & $(1.07)$ & $(0.35)$ & $(0.70)$ & $(0.70)$ & $(0.23)$ & $(0.43)$ \\
\hline \multirow{2}{*}{$\mathrm{HH}$ head is literate ${ }^{\dagger}$} & 0.49 & 0.45 & -0.03 & 0.39 & 0.39 & -0.01 & -0.03 \\
\hline & $(0.04)$ & $(0.04)$ & $(0.05)$ & $(0.02)$ & $(0.02)$ & $(0.03)$ & $(0.04)$ \\
\hline \multirow[t]{2}{*}{ Household size } & 5.80 & 6.30 & 0.50 & 5.00 & 5.41 & 0.41 & 0.09 \\
\hline & $(0.17)$ & $(0.18)$ & $(0.07)$ & $(0.09)$ & $(0.09)$ & $(0.03)$ & $(0.07)$ \\
\hline \multirow[t]{2}{*}{ Number of oxen } & 2.11 & 2.04 & -0.07 & 1.29 & 1.28 & -0.02 & -0.05 \\
\hline & $(0.11)$ & $(0.11)$ & $(0.08)$ & $(0.05)$ & $(0.05)$ & $(0.04)$ & $(0.08)$ \\
\hline \multirow[t]{2}{*}{ Agricultural $\mathrm{hh}^{\dagger}$} & 0.85 & 0.82 & -0.03 & 0.88 & 0.86 & -0.03 & -0.01 \\
\hline & $(0.03)$ & $(0.03)$ & $(0.04)$ & $(0.01)$ & $(0.02)$ & $(0.02)$ & $(0.03)$ \\
\hline \multirow[t]{2}{*}{ Iron sheets roof ${ }^{\dagger}$} & 0.68 & 0.75 & 0.07 & 0.53 & 0.60 & 0.07 & 0.00 \\
\hline & $(0.04)$ & $(0.03)$ & $(0.05)$ & $(0.02)$ & $(0.02)$ & $(0.03)$ & $(0.03)$ \\
\hline \multirow[t]{2}{*}{ Dist. to town (mins) } & 42.86 & 40.83 & -2.03 & 76.97 & 80.48 & 3.52 & $-5.55^{* *}$ \\
\hline & $(2.18)$ & $(2.01)$ & $(1.51)$ & $(1.72)$ & $(1.87)$ & $(1.54)$ & $(2.71)$ \\
\hline \multirow[t]{2}{*}{ Total land size (ha) } & 1.65 & 1.71 & 0.05 & 1.28 & 1.30 & 0.02 & 0.04 \\
\hline & $(0.07)$ & $(0.07)$ & $(0.06)$ & $(0.03)$ & $(0.03)$ & $(0.02)$ & $(0.05)$ \\
\hline \multirow[t]{2}{*}{ Land size (ha/aeu) } & 0.38 & 0.35 & -0.03 & 0.34 & 0.32 & -0.02 & -0.01 \\
\hline & $(0.02)$ & $(0.02)$ & $(0.02)$ & $(0.01)$ & $(0.01)$ & $(0.01)$ & $(0.02)$ \\
\hline \multirow[t]{2}{*}{ Livestock (\$) } & 1315.04 & 1256.17 & -58.87 & 792.16 & 823.33 & 31.18 & $-90.04^{*}$ \\
\hline & $(74.34)$ & $(65.07)$ & (58.05) & (30.08) & (30.59) & $(22.42)$ & $(51.04)$ \\
\hline \multirow[t]{2}{*}{ Off-farm income (\$) } & 81.51 & 33.72 & -47.79 & 65.64 & 33.86 & -31.78 & -16.02 \\
\hline & (11.83) & $(6.83)$ & (12.42) & (6.09) & $(4.54)$ & $(6.48)$ & (13.09) \\
\hline \multicolumn{8}{|c|}{ Land use and labour supply in person-days: } \\
\hline \multirow[t]{2}{*}{ Household labour } & 178.20 & 157.45 & -20.74 & 92.36 & 93.89 & 1.53 & $-22.28^{* * *}$ \\
\hline & $(9.29)$ & $(6.85)$ & $(7.87)$ & $(3.23)$ & $(3.08)$ & $(2.60)$ & $(6.41)$ \\
\hline \multirow[t]{2}{*}{ - Children } & 14.27 & 8.02 & -6.25 & 2.40 & 4.14 & 1.74 & $-7.99^{* * *}$ \\
\hline & $(1.50)$ & $(1.04)$ & $(1.64)$ & $(0.31)$ & $(0.52)$ & $(0.51)$ & $(1.30)$ \\
\hline \multirow[t]{2}{*}{ - Adults } & 163.93 & 149.44 & -14.49 & 89.96 & 89.76 & -0.20 & $-14.29^{* *}$ \\
\hline & $(8.57)$ & $(6.50)$ & $(7.44)$ & (3.13) & $(2.86)$ & $(2.60)$ & $(6.22)$ \\
\hline \multirow[t]{2}{*}{ Debo workers } & 8.91 & 8.23 & -0.68 & 6.51 & 7.73 & 1.23 & $-1.91^{*}$ \\
\hline & $(0.72)$ & $(0.69)$ & $(0.97)$ & $(0.47)$ & $(0.48)$ & $(0.60)$ & $(1.15)$ \\
\hline \multirow[t]{2}{*}{ Hired workers } & 0.17 & 0.75 & 0.59 & 0.91 & 1.03 & 0.12 & 0.46 \\
\hline & $(0.05)$ & $(0.32)$ & $(0.33)$ & $(0.22)$ & $(0.21)$ & $(0.25)$ & $(0.46)$ \\
\hline \multirow[t]{2}{*}{ Land size plough (ha) } & 1.53 & 1.54 & 0.02 & 1.11 & 1.18 & 0.06 & -0.05 \\
\hline & $(0.08)$ & $(0.07)$ & $(0.07)$ & $(0.04)$ & $(0.04)$ & $(0.03)$ & $(0.07)$ \\
\hline \# of households & 179 & 179 & 179 & 490 & 490 & 490 & 669 \\
\hline
\end{tabular}

Note: The table describes changes of household characteristics and labour supply between 1999 and 2002. Standard errors are in parentheses and significance levels are denoted as follows: ${ }^{*} \mathrm{p}<0.10,{ }^{* *} \mathrm{p}<0.05,{ }^{* * *}$ $\mathrm{p}<0.01$. The significance levels for coefficients in columns "diff.(1)" and "diff.(2)" are reported for t-tests on paired data of the equality of the means over time for each of the variables for households with and without land certificates. The significance levels for coefficients in column "diff. (1) - (2)" are reported for the test of equality between "diff.(1)" and "diff.(2)".

${ }^{\dagger}$ Indicates dummy variables.

use dynamics is constant over time, the average impact of the land registration programme on the treated households is identified (Abadie, 2005). ${ }^{17}$

\footnotetext{
${ }^{17}$ I relax the assumption about unobservable changes in Subsection 6.4 when we discuss the robustness of the estimates.
} 


\subsection{Empirical Strategy}

Assume each household had two potential outcomes $\mathbf{y}_{1 t}$, and $\mathbf{y}_{0 t} \cdot \mathbf{y}_{1 t}$ is the value of the variable of interest $\mathbf{y}$ for a household with a land certificate at time $t . \mathbf{y}_{0 t}$ is the value of $\mathbf{y}$ had the household not received its land certificate at time $t . \mathbf{d}_{t}$ is an indicator of whether or not the household has received a certificate for its landholdings at time $t$. The parameter of interest is the average effect of the land certificate on the treated (ATT):

$$
\mathrm{ATT} \equiv \mathbb{E}\left(\mathbf{y}_{1 t}-\mathbf{y}_{0 t} \mid \mathbf{d}_{t}=1\right)
$$

Since $\mathbf{y}_{0 t}$ is never observed for a treated household, the ATT cannot be directly estimated. Assume $\mathbf{y}_{0 b}$ is the value of $\mathbf{y}$ at the baseline when no land certificate was issued yet and $\Delta \mathbf{y}_{t} \equiv$ $\mathbf{y}_{t}-\mathbf{y}_{b}$ represents the change of $\mathbf{y}$ between time $t$ and the baseline $b$. It is possible to show that:

$$
\begin{aligned}
\mathrm{ATT} & =\int \mathbb{E}\left(\mathbf{y}_{1 t}-\mathbf{y}_{0 t} \mid \mathbf{d}_{t}=1, \mathbf{x}_{b}\right) \times \mathrm{d} \mathbf{F}\left(\mathbf{x}_{b} \mid \mathbf{d}_{t}=1\right) \\
& =\int\left[\mathbb{E}\left(\left(\mathbf{y}_{1 t}-\mathbf{y}_{0 b}\right)-\left(\mathbf{y}_{0 t}-\mathbf{y}_{0 b}\right) \mid \mathbf{d}_{t}=1, \mathbf{x}_{b}\right)\right] \times \mathrm{d} \mathbf{F}\left(\mathbf{x}_{b} \mid \mathbf{d}_{t}=1\right) \\
& =\int\left[\mathbb{E}\left(\mathbf{y}_{1 t}-\mathbf{y}_{0 b} \mid \mathbf{d}_{t}=1, \mathbf{x}_{b}\right)-\mathbb{E}\left(\mathbf{y}_{0 t}-\mathbf{y}_{0 b} \mid \mathbf{d}_{t}=1, \mathbf{x}_{b}\right)\right] \times \mathrm{d} \mathbf{F}\left(\mathbf{x}_{b} \mid \mathbf{d}_{t}=1\right) .
\end{aligned}
$$

Hence, the ATT can be estimated if there are treated and untreated households with similar characteristics at the baseline, $\mathbf{x}_{b}$, so that:

$$
\mathbb{E}\left(\mathbf{y}_{0 t}-\mathbf{y}_{0 b} \mid \mathbf{d}_{t}=1, \mathbf{x}_{b}\right)=\mathbb{E}\left(\mathbf{y}_{0 t}-\mathbf{y}_{0 b} \mid \mathbf{d}_{t}=0, \mathbf{x}_{b}\right)
$$

If Equation (8) holds, then

$$
\begin{aligned}
\mathrm{ATT} & =\int\left[\mathbb{E}\left(\mathbf{y}_{1 t}-\mathbf{y}_{0 b} \mid \mathbf{d}_{t}=1, \mathbf{x}_{b}\right)-\mathbb{E}\left(\mathbf{y}_{0 t}-\mathbf{y}_{0 b} \mid \mathbf{d}_{t}=0, \mathbf{x}_{b}\right)\right] \times \mathrm{d} \mathbf{F}\left(\mathbf{x}_{b} \mid \mathbf{d}_{t}=1\right) \\
& =\int\left[\mathbb{E}\left(\Delta \mathbf{y}_{t} \mid \mathbf{d}_{t}=1, \mathbf{x}_{b}\right)-\mathbb{E}\left(\Delta \mathbf{y}_{t} \mid \mathbf{d}_{t}=0, \mathbf{x}_{b}\right)\right] \times \mathrm{d} \mathbf{F}\left(\mathbf{x}_{b} \mid \mathbf{d}_{t}=1\right) .
\end{aligned}
$$

It follows that averaging the differences in the change over time of $\mathbf{y}$ between treated and untreated households with similar initial characteristics gives an unbiased estimate of the ATT.

A key aspect of the land registration programme in Amhara is that "selection of villages to be certified was the responsibility of woreda officials, who determined a roll-out plan in campaign style, 
moving from village to village to maximize targets" (see Deininger et al., 2011, p. 317). Besides, administrative procedures pending the issuance of the land certificates create a discontinuity in the timing of the receipt of the land certificates. Therefore, we will observe two sources of variation. First, households with similar characteristics but living in different villages will receive their land certificates at different moment because of the order in which the registrations activities spread from one kebele to another. Second, within the same kebele, households with similar characteristics will receive their land certificates at different point in time because administrative constraints prevent all the land certificates to be issued at once.

Though we should suspect that some households could leverage their resources to fast track the issuance of their land certificates, we should also acknowledge that the discontinuity in the timing of the issuance of the land certificates is to some extent exogenous to households. This provides an opportunity to meet the requirements of conditional independence stated in Equation (8).

Considering the limited size of the sample and the large set of characteristics $\mathbf{x}_{b}$, it is not possible to match each treated household with an untreated household with similar observable characteristics at baseline. Instead, we use the semi-parmetric difference-in-difference estimator of Abadie (2005) that reweighs treated and untreated households based on their probability $\pi\left(\mathbf{x}_{b}\right) \equiv \mathbb{P}\left(\mathbf{d}_{t}=1 \mid \mathbf{x}_{b}\right)$ of receiving a land certificate before June 2006. If $\pi\left(\mathbf{x}_{b}\right)<$ 1 and $\mathbb{P}\left(\mathbf{d}_{t}=1\right)>0$, Abadie (2005) shows that the sample analogue of

$$
\mathbb{E}\left(\frac{\Delta \mathbf{y}_{t}}{\mathbb{P}\left(\mathbf{d}_{t}=1\right)} \times \frac{\mathbf{d}_{t}-\pi\left(\mathbf{x}_{b}\right)}{1-\pi\left(\mathbf{x}_{b}\right)}\right)
$$

gives an unbiased estimate of the ATT. The estimator is a weighted average of the temporal changes $\Delta \mathbf{y}_{t}$ of the outcome $\mathbf{y}$. In short, it weights the untreated by their probability of being treated.

\subsection{Estimation}

The probability of receiving the land certificate before June $2006, \pi\left(\mathbf{x}_{b}\right)$ or propensity score, is estimated based on household characteristics, self assessment of soil quality, type of crops grown, agricultural inputs, land endowment, land size cultivated and labour supply observed at baseline. Though extensive, the questionnaire covers a limited set of potential confounders and we do not observe certain characteristics that may simultaneously drive selection into 
treatment and affect dynamics of land and time use. For instance, though age composition of children can affects change of child labour over time in a non-linear fashion, the questionnaire does not detail age composition of children involved in agricultural activities. Likewise, the questionnaire provides no information about characteristics of non-household members that take part in labour sharing parties. Our strategy might therefore not be able to achieve a decent reweighing to address selection issue when estimation the effect of the land registration activities on child and debo labour.

On a similar note, we may also be concerned that time-varying unobserved heterogeneity of households may simultaneously drive the timing of the issuance of the land certificate and time allocated to farming activities. For instance, households with ties within the administration may fast track the issuance of their land certificates. In that scenario, households whose social capital had broadened between 1999 and 2007 would be in position to fast track the issuance of their land certificate. Depending on the relationship between social capital and labour supply, we could therefore observe a change of labour supply for households with land certificates that would be at least partly driven by the change of social capital. This is serious threat to identification strategy.

Though we do not observe household social capital at baseline, the end line survey includes several questions about participation of household members in community organization for the past three and five years. ${ }^{18}$ This allows us to recover information pertaining to participation to community organization in 2002, 2004 and 2007. However, as information was not recovered about participation to community organization seven years ago, it is not possible to extract information about household social capital at baseline in 1999. Assuming that the social capital mobilized by household in 2002 is a valid proxy for the social capital they had in 1999, we have checked sensitivity of the propensity score to the inclusion of those variable (see Table A-5).

The results suggest that few household characteristics predict the timing of the issuance of land certificates. Households that lived close to the district town in 1999 were more likely to get their land certificate on time for the meher of 2006-07. Likewise, female headed households

\footnotetext{
${ }^{18}$ The organizations considered are the kebele administration (comprised of the council, the executive committee, the land use and administrative committee), the kebele social court, political parties, religious assembly committee, burial association and micro-insurance institutions.
} 
and households with flat land were also more likely to receive their certificate by June $2006 .{ }^{19}$ Lastly, though we find that social capital at round 2 is positively correlated with early issuance of land certificates, the coefficients are not statistically significant. Hence, heterogeneity with respect to social capital is less likely to bias the results.

To estimate the ATT, the propensity score is approximated using a polynomial series of the predictors as observed at the baseline and plugged into the sample analogue of Equation (10). ${ }^{20}$ The measurement errors related to the approximation of the propensity scores are then taken into account when estimating the standard error of the ATT (see Abadie, 2005, for details). Considering that the semi-parametric difference in difference estimator does not rely on a parametric specification of the link between labour dynamic and the treatment intervention, there is for now no formal procedure to account for possible within cluster auto-correlation. ${ }^{21}$ Consequently our estimates do not account for potential within kebele clustering effect.

\subsection{Testing Parallel Trend}

In this section we test the parallel trend assumption and check if we can detect any effect of the land certificates on the treated household prior to the land registration activities. To the extent that our approach is able to address the selection issue and there is no unobservable time varying confounding factor, we should not detect any treatment effect on the treated either in 2002 nor in 2004. For comparison, we also estimate the ATT in year $t^{\prime}$ with a household fixed effect based on the following model:

$$
\mathbf{y}_{i t}=\alpha_{i}+\delta \cdot \mathbb{1}\left(t=t^{\prime}\right)+\gamma \cdot \text { treated } \times \mathbb{1}\left(t=t^{\prime}\right)+\varepsilon_{i t} .
$$

where $\alpha_{i}$ is the household fixed effect and $\gamma$ is the average treatment effect on the treated.

\footnotetext{
${ }^{19}$ Female headed households have fewer plots and may receive their land certificates ahead of households with more landholdings. As town develop on less hilly terrain, elevation and plot steepness is often positively correlated with distance to town. So the negative correlation between plot steepness can be partly correlated to their distance from town or the fact that kebeles which are on hilly terrain were more difficult of access and reached at later stages of the registration activities.

${ }^{20}$ Even though the approximation improves for higher degrees, the estimation becomes less precise. Then, we imposed a common support for the propensity score by trimming the treated households whose score is higher than the maximum score of the untreated households. Similarly, we have trimmed the untreated households whose propensity score is smaller than the minimum score of the untreated households. Therefore, the estimates presented in this paper are only valid for the households with a land certificate and which have a propensity score in the common support region. See Figure A-2 for indication of the overlap between the propensity scores of treated and untreated households.

${ }^{21}$ Given the small number of kebeles covered in this study and in an attempt to address possible clustering at kebele level, we have performed a percentile- $t$ bootstrap to estimate the risk of type- 1 error associated with our estimates. As described in Cameron and Miller (2015), the percentile- $t$ bootstrap has the advantage to be applicable to a widerange of estimators. Our results show estimated p-values which are above normal standards for all estimates.
} 
Table 3: Impact of Land Registration on the Treated Before 2007.

\begin{tabular}{|c|c|c|c|c|c|c|}
\hline \multirow{2}{*}{ Outcomes } & \multicolumn{3}{|c|}{ ATT in 2004} & \multicolumn{3}{|c|}{ ATT in 2002} \\
\hline & Mean & $(\mathrm{ABD})$ & (OLS) & Mean & $(\mathrm{ABD})$ & (OLS) \\
\hline \multicolumn{7}{|c|}{ Labor Supply in measured in person-day } \\
\hline Child labor & $\begin{array}{r}13.335 \\
(1.760)\end{array}$ & $\begin{array}{c}4.126^{*} \\
(2.232)\end{array}$ & $\begin{array}{r}0.733 \\
(1.523)\end{array}$ & $\begin{array}{r}7.795 \\
(1.094)\end{array}$ & $\begin{array}{r}-2.470 \\
(1.808)\end{array}$ & $\begin{array}{l}-4.176^{* * *} \\
(1.264)\end{array}$ \\
\hline - Girls & $\begin{array}{r}4.944 \\
(0.914)\end{array}$ & $\begin{array}{r}1.163 \\
(0.992)\end{array}$ & $\begin{array}{r}0.285 \\
(0.720)\end{array}$ & $\begin{array}{r}3.585 \\
(0.732)\end{array}$ & $\begin{array}{r}-0.929 \\
(1.267)\end{array}$ & $\begin{array}{l}-0.871 \\
(0.656)\end{array}$ \\
\hline - Boys & $\begin{array}{r}8.391 \\
(1.249)\end{array}$ & $\begin{array}{r}2.963 \\
(2.076)\end{array}$ & $\begin{array}{r}0.447 \\
(1.221)\end{array}$ & $\begin{array}{r}4.210 \\
(0.727)\end{array}$ & $\begin{array}{r}-1.541 \\
(1.381)\end{array}$ & $\begin{array}{l}-3.305^{* * *} \\
(0.949)\end{array}$ \\
\hline Adult labor & $\begin{array}{r}119.789 \\
(6.881)\end{array}$ & $\begin{array}{r}3.113 \\
(7.531)\end{array}$ & $\begin{array}{l}-16.176^{* *} \\
(7.357)\end{array}$ & $\begin{array}{r}144.074 \\
(6.929)\end{array}$ & $\begin{array}{c}11.927 \\
(7.440)\end{array}$ & $\begin{array}{r}-3.143 \\
(6.409)\end{array}$ \\
\hline - Women & $\begin{array}{l}38.857 \\
(2.436)\end{array}$ & $\begin{array}{r}2.673 \\
(2.761)\end{array}$ & $\begin{array}{r}-3.478 \\
(2.503)\end{array}$ & $\begin{array}{r}45.691 \\
(2.538)\end{array}$ & $\begin{array}{r}3.311 \\
(3.118)\end{array}$ & $\begin{array}{r}0.507 \\
(2.425)\end{array}$ \\
\hline - Men & $\begin{array}{r}80.932 \\
(4.827)\end{array}$ & $\begin{array}{r}0.439 \\
(5.781)\end{array}$ & $\begin{array}{l}-12.698^{* *} \\
(5.401)\end{array}$ & $\begin{array}{r}98.384 \\
(4.942)\end{array}$ & $\begin{array}{r}8.616 \\
(5.390)\end{array}$ & $\begin{array}{r}-3.650 \\
(4.578)\end{array}$ \\
\hline Other labor & $\begin{array}{r}14.255 \\
(1.763)\end{array}$ & $\begin{array}{l}-8.283^{* *} \\
(3.220)\end{array}$ & $\begin{array}{l}-10.085^{* * *} \\
(3.210)\end{array}$ & $\begin{array}{r}8.674 \\
(0.835)\end{array}$ & $\begin{array}{l}-2.736^{* *} \\
(1.172)\end{array}$ & $\begin{array}{r}-1.055 \\
(1.306)\end{array}$ \\
\hline - Debo labor & $\begin{array}{r}12.602 \\
(1.506)\end{array}$ & $\begin{array}{l}-8.963^{* * *} \\
(3.057)\end{array}$ & $\begin{array}{l}-9.912^{* * *} \\
(2.820)\end{array}$ & $\begin{array}{r}7.860 \\
(0.696)\end{array}$ & $\begin{array}{l}-2.897^{* * *} \\
(1.069)\end{array}$ & $\begin{array}{r}-1.590 \\
(1.152)\end{array}$ \\
\hline - Hired labor & $\begin{array}{r}1.652 \\
(0.488)\end{array}$ & $\begin{array}{r}0.680 \\
(0.539)\end{array}$ & $\begin{array}{r}-0.173 \\
(0.836)\end{array}$ & $\begin{array}{r}0.814 \\
(0.358)\end{array}$ & $\begin{array}{r}0.161 \\
(0.481)\end{array}$ & $\begin{array}{r}0.535 \\
(0.506)\end{array}$ \\
\hline Land size ploughed (ha) & $\begin{array}{r}1.948 \\
(0.187)\end{array}$ & $\begin{array}{c}0.205^{*} \\
(0.121)\end{array}$ & $\begin{array}{c}0.372^{* * *} \\
(0.130)\end{array}$ & $\begin{array}{r}1.442 \\
(0.070)\end{array}$ & $\begin{array}{r}0.014 \\
(0.075)\end{array}$ & $\begin{array}{r}-0.031 \\
(0.074)\end{array}$ \\
\hline Number of households & 161 & 591 & 591 & 161 & 591 & 591 \\
\hline
\end{tabular}

Note: Column (ABD) shows estimates of the ATT using the estimator of Equation (10). Column (OLS) reports estimates of the coefficient $\gamma$ of Equation (11). For comparison, we have restricted the sample to the common support of 591 households. Standard errors are in parentheses and do not account for possible clustering at the kebele level. Significance levels are denoted as follows: ${ }^{*} \mathrm{p}<0.10,{ }^{* *} \mathrm{p}<0.05,{ }^{* * *} \mathrm{p}<0.01$.

Table 3 shows the estimates of the ATT on land and time use during the meher of 2001-02 and 2003-04. The coefficients in column (ABD) reports estimates of the ATT using the semiparametric difference-in-difference estimator. Column (OLS) shows the estimate of the coefficient $\gamma$ of Equation (11). At the time of the meher of 2001-02, the land registration activities had not started yet. Hence, we expect no significant effect of the land certificate on land and time use during that agricultural season for the treated households. In June 2003, the land registration activities were ongoing in one kebele. Though no land certificate had been issued yet, those households had strong incentives to signal their land use at the time of the land demarcation activities. In that case, we are likely to observe an increase of land size cultivated and time allocated to farming activities during the meher of 2003-04.

The results of Table 3 indicate that after matching the dynamics of land and time use by adult members were similar for treated and untreated households during the meher of 2001-02 and 2003-04. The assumption of conditional parallel trend expressed in Equation (8) is thus likely 
to hold for the adult labour during meher of 2006-07.22 Lastly, as expected, our strategy is not able to satisfactorily address heterogeneity between treated and untreated households that underline the demand for debo labour. Hence, we do not report on the effects of the land registration programme on that source of labour.

\subsection{Alternative Estimators}

Other matching estimators can be combined with a difference-in-difference strategy to estimate the ATT. For comparison, we use the propensity score and nearest neighbour matching estimators which are among the most widely used estimators for quasi experimental identification. Both techniques impute the missing potential outcome of each treated household by using the average time allocated to farming activities by similar untreated households. Where the propensity score matching estimator defines similarity based on estimated propensity score, the nearest neighbour matching defines it based on a weighted function of the characteristics of each household. Given recent advances in the econometrics (Abadie and Imbens, 2006, 2008, 2011, 2016), it is now possible to produce consistent estimates of the standard errors of both types of estimators that account also for the estimation of the metric used to select the appropriate control group. While these advances make the propensity score and nearest neighbour matching estimators attractive alternatives, the semi-parametric difference-in-difference estimator from Equation (10) is our preferred estimator for the purpose of this paper. ${ }^{23}$

\footnotetext{
${ }^{22}$ Although not statistically different from zero, the results of Table 3 also show that adult labour increased in 2002 by 12 person-days for treated households. Actually, the land registration activities started in the pilot project areas around that same time. One of the pilot village - Addissena Gulit - is located in the same district as the kebeles of this study. It is likely that the households that are close to pilot villages mistook the registration activities for a land redistribution programme and have increased their presence on their farm in anticipation during the meher 2001-02 to signal land use. Later, information campaigns about the registration activities were carried to clarify the objectives and farmers were invited to form land administration and use committees at their kebele and sub-kebele levels (Getahun, 2006). Then, anticipation detected in 2001-02 faded away and the level of labour supply observed in the treated households in 2004 came back to the 1999 level.

${ }^{23}$ The propensity score and nearest neighbour matching estimators produce estimates with larger standard errors compared to the semi-parametric difference-in-difference estimator from Equation (10). This may be due to the fact that these estimators compare each treated household to its counterfactual. Since households with same index (propensity score of weighted function of household characteristics) might still have different characteristics, this approach might be a better fit for larger sample size. In comparison, the semi-parametric difference-in-difference is less parsimonious and differences out the weighted average across treated and untreated group. Though this approach does not allow us to have counterfactual for each treated household, it is simple and seemingly generates estimates with smaller standard errors. Table A-7 reproduces estimates of the ATT, during the agricultural seasons of 2001-02 and 2003-04, using the propensity score and nearest neighbour matching estimators. The estimates produced confirm most conclusions reached from analysing Table 3 and suggest that the parallel trend assumption hods in most cases, except with child and debo labour.
} 


\section{Results}

\subsection{Land Registration and Time Allocation}

Table 4 shows estimates of change in land and time use during the meher of 2006-07 for households that received their land certificates ahead of the agricultural season. The dependent outcomes are presented in the first column of the table and include labour supply by children and adult household members, labour supply by hired workers and land size cultivated. The column "average level" reports the average level of each outcome for the treated households of the common support as measured during the meher of 2006-07. The other columns display the ATT using different matching techniques. The coefficients reported in column (ABD) are estimated using the sample analogue of Equation (10). Columns (PSM), (NNM) show estimates of the same effect using a propensity score and nearest neighbour matching estimator respectively.

The results presented in Table 4 consistently show that labour supply of male adults in the treated households has decreased by at least 13 person-days following the land registration programme. ${ }^{24}$ This represents a decrease of $13.2 \%$ of the average time allocated to farming activities by male adults in the treated households, had the land registration programme not taken place. Completion of the land registration programme through the issuance of land certificates is associated with no statistically significant change of labour supplied by adult women or girls. We find no robust effect on child labour supply. However, labour from hired workers has increased by 1.2 to 1.6 person-days. This represents a large increase since the treated households hired on average 0.1 person-day of work during the meher 1998-99. It might indicate that with their land demarcated and registered, the land certificate holders can hire landless workers without compromising their claim to land. Lastly, there is evidence that the increase of and size cultivated detected in 2004 is also observed in 2007. This suggests that the reduction of time allocated to farming activities is not driven by a reduction of and size cultivated.

To further understand the mechanism behind the reduction of time allocated to farming activities by households with a land certificate we report in Table 5 the ATT of the issuance of the land certificates on labour supply by agricultural task. We find that labour supply during pre-

\footnotetext{
${ }^{24}$ While, the ATT on labour supply from men is not significant at the conventional level with PSM matching estimator, it is worth pointing out that the associated risk of type 1 error is estimated at $10.3 \%$.
} 
Table 4: Impact of Land Registration on the Treated during meher 2006-07.

\begin{tabular}{lrccc}
\hline \multirow{2}{*}{ Outcomes } & Average & \multicolumn{3}{c}{ ATT } \\
\cline { 5 - 5 } & level & $(\mathrm{ABD})$ & $(\mathrm{PSM})$ & $(\mathrm{NNM})$ \\
\hline Child labor & 15.323 & 3.755 & 3.026 & -3.008 \\
& $(1.897)$ & $(2.632)$ & $(3.745)$ & $(3.082)$ \\
- Girls & 4.491 & 1.205 & 0.550 & -0.885 \\
& $(0.794)$ & $(1.317)$ & $(1.279)$ & $(1.239)$ \\
- Boys & 10.832 & 2.551 & 2.477 & -2.123 \\
Adult labor & $(1.479)$ & $(2.736)$ & $(3.145)$ & $(2.598)$ \\
& 135.540 & -12.042 & -18.301 & $-22.001^{*}$ \\
- Women & $(7.758)$ & $(7.917)$ & $(14.644)$ & $(13.164)$ \\
& 46.854 & 1.450 & -2.499 & -1.251 \\
- Men & $(2.855)$ & $(3.178)$ & $(6.046)$ & $(4.607)$ \\
Hired labor & 88.686 & $-13.492^{* *}$ & -15.802 & $-20.750^{* *}$ \\
Land size ploughed (ha) & $(5.142)$ & $(5.832)$ & $(9.688)$ & $(9.682)$ \\
& 1.342 & $1.181^{* * *}$ & $1.602^{* * *}$ & $1.627^{*}$ \\
& $(0.280)$ & $(0.336)$ & $(0.526)$ & $(0.885)$ \\
& 2.191 & 0.180 & $0.419^{*}$ & $0.418^{* *}$ \\
\hline Number of households & $(0.125)$ & $(0.140)$ & $(0.217)$ & $(0.179)$ \\
\hline \hline
\end{tabular}

Note: Column "average level" reports the average level of each outcome for the treated households of the common support as measured during the meher of 2006-07. Column (1) shows estimates of the ATT using the estimator of Equation (10). Column (PSM) shows estimates of the ATT based on propensity score matching. The ATT reported in (NNM) are estimated with the nearest neighbour matching estimator. The propensity score used to match treated and untreated households is estimated using as predictors households' demographic, characteristics of the production function and the type of crops grown, land endowment, land size cultivated and labour supply during the meher 1998-99.

Standard errors in parentheses account for the fact that the propensity scores are estimated but are not clustered at village level. Significance levels are denoted as follows: ${ }^{*} \mathrm{p}<0.10,{ }^{* *} \mathrm{p}<0.05,{ }^{* * *} \mathrm{p}<0.01$.

planting activities by male adults in the treated households has decreased by 9 person-days. ${ }^{25}$ Hence, the households who registered their land have ploughed the a larger size of their landholdings with less labour supply. Table 5 also shows a slight increase of time allocated to preplanting activities by male children and provides evidence that the increase of labour supply by hired workers is mainly concentrated on labour intensive tasks like harvesting and threshing. The increase of time allocated to farming activities by children can also indicate a substitution of guard labour by male adult to less intense and effective guarding activities by male children. This interpretation would echo the substitution between child and adult labour reported by Field (2007). It also raises concerns regarding child schooling as time spent on farm activities might compete with time spent at school. 
Table 5: Impact of Land Registration by Task and Source of Labour.

\begin{tabular}{lrrrrrrrr}
\hline \multirow{2}{*}{ Outcomes } & \multicolumn{2}{c}{ Male children } & & \multicolumn{2}{c}{ Male adults } & & \multicolumn{2}{c}{ Hired workers } \\
\cline { 2 - 3 } \cline { 7 - 8 } & Mean & ATT & & Mean & ATT & & Mean & ATT \\
\hline Labour supply & & & & & & & & \\
- Pre-planting & 1.671 & $0.946^{* *}$ & & 22.196 & $-9.513^{* * *}$ & & 0.000 & $0.066^{*}$ \\
& $(0.372)$ & $(0.482)$ & & $(1.384)$ & $(2.401)$ & & $(0.000)$ & $(0.035)$ \\
- Planting & 2.168 & 0.422 & & 14.404 & -0.164 & & 0.000 & 0.042 \\
& $(0.317)$ & $(0.489)$ & & $(1.104)$ & $(1.149)$ & & $(0.000)$ & $(0.027)$ \\
- Weeding & 2.845 & 0.293 & & 18.053 & -1.972 & & 0.031 & 0.035 \\
& $(0.454)$ & $(0.808)$ & & $(1.257)$ & $(1.788)$ & & $(0.026)$ & $(0.146)$ \\
- Harvest & 1.913 & 0.368 & & 18.842 & 0.475 & & 1.050 & $0.750^{* * *}$ \\
& $(0.316)$ & $(0.631)$ & & $(1.227)$ & $(1.489)$ & & $(0.213)$ & $(0.217)$ \\
- Threshing & 2.236 & 0.523 & & 15.193 & $-2.318^{*}$ & & 0.261 & $0.287^{* * *}$ \\
& $(0.355)$ & $(0.789)$ & & $(1.001)$ & $(1.290)$ & & $(0.101)$ & $(0.101)$ \\
\hline Number of households & 161 & 591 & & 161 & 591 & & 161 & 591 \\
\hline \hline
\end{tabular}

Note: The table shows the average effect of the land certificate on labour supply across agricultural tasks. The effect is measured depending on the source of labour (male children and adults of the households and hired workers). The ATT is estimated using the estimator presented in Equation (10) and the standard errors are computed as described in Abadie (2005). The column "Mean" reports the average level of the dependent variable as observed among the treated households during the agricultural season 2006-07. The column ATT shows the average effect of the land certificates. Standard errors are in parentheses and significance levels are denoted as follows: ${ }^{*} \mathrm{p}<0.10,{ }^{* *}$ $\mathrm{p}<0.05,{ }^{* * *} \mathrm{p}<0.01$.

\subsection{Heterogeneous effects of Land Registration}

Table 6 compares the average effect of the land certificates across different groups of land certificate holders. As predicted in the theoretical framework in Section 3, the results presented in Table 6 show that the effect of the land certificate on labour allocated to pre-planting activities is larger for households endowed with a larger land size in 1999. Likewise, we also find evidence that the effect of the programme is higher for households with a fragmented land endowment. Indeed these households have to provide guard labour on each plot. They are therefore more likely to supply more guard labour than households with fewer plots. There is, however, no evidence that the effect of the land certificate varies either with respect to the prior level of perceived tenure security or the average distance between the plots and the household's homestead.

\subsection{Exploring Potential Mechanisms}

The main results of this study suggest that the reduction of the time allocated to pre-planting activities is driven by a reduction of guard labour. Unlike other agricultural tasks, pre-planting prepares the soil for cultivation and often requires leaving the field without visible sign of

\footnotetext{
${ }^{25}$ This represents a decrease of $30 \%$ of the time that would have been allocated to pre-planting activities.
} 
Table 6: Heterogeneity of the Impact of Land Registration on Land and Time Use.

\begin{tabular}{lrrrr}
\hline & Mean & $(1)$ & $(2)$ & $(3)$ \\
\hline Outcome: Labour supply by male adults & & & & \\
Constant & 22.196 & $-9.513^{* * *}$ & 3.927 & 6.648 \\
& $(1.384)$ & $(2.401)$ & $(8.060)$ & $(10.526)$ \\
- Distance to the closest plot (mins) & & & 0.252 & 0.261 \\
& & & $(0.278)$ & $(0.284)$ \\
- Expected no land loss & & & -1.392 & -1.138 \\
& & & $(7.093)$ & $(7.286)$ \\
- Land endowment in 1998-99 (ha) & & & $-8.780^{* *}$ & \\
- Number of plots in 1998-99 & & & $(3.633)$ & $-2.382^{* *}$ \\
& & & & $(1.104)$ \\
Outcome: Land size ploughed (ha) & & & & \\
Constant & 2.191 & 0.180 & -0.573 & 0.316 \\
- Distance to the closest plot (mins) & $(0.125)$ & $(0.140)$ & $(0.599)$ & $(0.529)$ \\
& & & 0.016 & 0.008 \\
- Expected no land loss & & & $(0.014)$ & $(0.014)$ \\
- Land endowment in 1998-99 (ha) & & & 0.411 & 0.283 \\
- Number of plots in 1998-99 & & & $(0.521)$ & $(0.490)$ \\
\hline \hline
\end{tabular}

Note: The column "Mean" reports the average level of land and time use for pre-planting activities as observed among the treated households during the agricultural season 2006-07. Column (1) shows the "raw" average effect of the land certificates on the treated. In column (2) the effect is interacted with household characteristics observed prior to the issuance of land certificate. In particular, it investigates the variation of the effect of the land certificate on treated households with respect to expectation of land loss between 2004 and 2008 expressed in 2004, the walking distance to closest plot in minutes and the size of land endowment. In column (3) I ran the same regression as in (2) but replaced total land endowment by the number of disjunct plots cultivated in 1998-99. Standard errors are in parentheses and do not account for possible within kebele auto-correlation. Significance levels are denoted as follows: ${ }^{*} \mathrm{p}<0.10,{ }^{* *} \mathrm{p}<0.05,{ }^{* * *} \mathrm{p}<0.01$.

occupation until the most suitable time for planting. It is therefore the most suitable period for encroachment from neighbouring landholders. In our sample the treated households allocated an average of 40 person-days from male adults to pre-planting in 1999 compared to 22 in 2007. Likewise, threshing takes place at the end of the agricultural season and is accompanied by a land vacancy period during which the plots are left vacant without any visible sign of land use. Ploughing and threshing periods contrast with other labour intensive periods like harvesting and weeding activities where the crops cultivated are highly visible and suffice to signal land use. Interestingly, we find no statistically significant evidence of change of time allocated to harvesting and weeding following land registration. The non symmetric effect of the land registration programme across agricultural tasks lends support to the theory that vacant plots are at risk of encroachment by neighbours and guard labour is likely exercised throughout 
ploughing and after harvest to safeguard land claims.

Consequently, since time allocated to guarding activities has no production value, the issuance of the land certificates should have no impact on agricultural yield. Investigating the effect of the land certificates on agricultural yields, total labour supply, use of improved fertilizer and land size allocated to each crop, we find no evidence that total production decreased for the treated households after the issuance of the land certificates (see Table A-6). Actually the sign of the coefficient is positive for the agricultural season $2006-07$ but the estimate is not statistically different from zero. Likewise, we find no evidence that total labour supply decreases in the treated households following the issuance of the land certificate. However, given the heterogeneous effects of the land registration programme depending on the source of labour used, the estimation is not precise and the effect of the issuance of the land certificate on total labour supply is not statistically significant. The point estimate is however similar to the magnitude of the effect of the land certificate on time allocated to pre-planting activities. We also find no evidence that the reduction of labour supply by men is due to a change in the crops grown. The land size allocated to each crop does not vary with the issuance of the land certificate, except maybe for land size allocated to growing spices. However, the size of the impact and the share of land endowment allotted to spices are too small to explain the decrease of labour observed. ${ }^{26}$

Lastly, we find no evidence that the reduction of labour supply could be driven by an increase insecurity of the households that did not receive their land certificate on time. In June 2006 the land registration activities were still ongoing in the kebele Wolkie. If those households increase their labour supply to safeguard their landholdings this would lead to an overestimation of the effect of the issuance of the land certificates on the treated. When we exclude those households from the sample, we find that time allocated to pre-planting activities by male adults in treated households decreases by 9 person-days during the meher of 2006-07 — the same margin identified when the whole sample is used (see Table A-8).

\subsection{Robustness to Unobservable Heterogeneity}

To causally attribute the observed reduction of time allocated to farming activities to the land registration activities, we assumed that the timing of the receipt of the land certificates is exoge-

\footnotetext{
${ }^{26}$ Moreover, taking into account that the rate of false discoveries increases with the number of crops considered and that a Bonferroni corrected p-value of $1 \%$, i.e. $\frac{10 \%}{9}$, is the minimum required to detect a statistically meaningful effect of land registration on land size allotted across nine crops, the effect of land registration on land size used for growing spices is not statistically significant.
} 
nous to any unobservable factors that determine agricultural labour supply. That assumption was indirectly checked through the tests of parallel trend and we found no evidence that dynamics of agricultural labour supply varied across treated and untreated households prior to the issuance of land certificates. Moreover, the Swedish International Development Cooperation Agency (Sida) was the only donor agency operating in the kebeles covered by the survey and had no other programme with a timing similar to the land registration activities that could affect the amount of time allocated to farming activities. ${ }^{27}$

There remains however the theoretical risk that some unobserved variation of household characteristics could simultaneously affect the timing of the land certificates and reduce agricultural labour supply in the treated households. In this subsection we use insights from the procedure developed by Altonji et al. (2005) to gauge the size of the potential bias that such unobservable change of household characteristics could lead.

We consider a framework linking variation of labour supply between 1999 and 2007, $\Delta \mathbf{y}$, to the issuance of a land certificate, $\mathbf{d}$, and variation of household and landholding characteristics between 1999 and 2007:

$$
\Delta \mathbf{y}=\alpha \cdot \mathbf{d}+\Delta \mathbf{x}^{\prime} \gamma+\varepsilon
$$

where $\Delta \mathrm{x}$ represents exogenous change of observable household and landholding characteristics between the meher1998-99 and 2006-07 and $\varepsilon$ represents unobservable changes driving $\Delta \mathbf{y}$.

The issuance of the land certificates ahead of the agricultural season $\mathbf{d}$ depends on observable changes $\Delta \mathbf{x}$ and unobservable $\vartheta$ so that $\mathbf{d}=\Delta \mathbf{x}^{\prime} \beta+\vartheta$. Our discussion so far assumed that $\vartheta$ was exogenous to household characteristics. When the selection equation is accounted for, the conceptual framework of Equation (12) can be rewritten as follows:

$$
\Delta \mathbf{y}=\alpha \cdot \vartheta+\Delta \mathbf{x}^{\prime}(\gamma+\alpha \beta)+\varepsilon
$$

The OLS estimator of $\alpha$ is function of the unobserved characteristics that drive simultaneously

\footnotetext{
${ }^{27}$ See Tegnäs et al. (2009) for the activities carried out by SIDA. The report also claims that donors are discouraged from supporting the same district in order to yield balanced development outcomes across regions. Hence, the only programmes that could affect land and time use by households are those conducted by Sida or local governments.
} 
selection into treatment and labour supply:

$$
\operatorname{plim} \hat{\alpha} \simeq \alpha+\frac{\operatorname{Cov}(\vartheta, \varepsilon)}{\operatorname{Var}(\vartheta)}
$$

Equation (14) illustrates the attribution problem. When $\vartheta$ is exogenous, $\operatorname{Cov}(\vartheta, \varepsilon)=0$ and we can measure $\alpha$, the effect of the land certificate. If $\vartheta$ is an index of unobservable change of household characteristics that affect variation of labour supply, then $\operatorname{Cov}(\vartheta, \varepsilon) \neq 0$, the OLS estimates are biased and there is a risk of wrongly mis-attributing the effect of other variables to the issuance of land certificates. Consequently we can have an estimate of treatment effect $\hat{\alpha} \neq 0$ even though $\alpha=0$.

Assuming land certificates have no effect on time allocated to agricultural activities and that $\vartheta$ is an index of unobservable change of household characteristics that determine issuance of land certificate and labour supply, we can quantify the size of the bias $\frac{\operatorname{Cov}(\vartheta, \varepsilon)}{\operatorname{Var}(\vartheta)}$. Let's assume that the difference across treatment groups of change of labour supply attributable to change in observable characteristics is proportional to the difference of labour dynamics driven by unobservables, i.e.:

$$
\frac{\mathbb{E}(\varepsilon \mid \mathbf{d}=1)-\mathbb{E}(\varepsilon \mid \mathbf{d}=0)}{\operatorname{Var}(\varepsilon)}=\frac{\mathbb{E}\left(\Delta \mathbf{x}^{\prime} \gamma \mid \mathbf{d}=1\right)-\mathbb{E}\left(\Delta \mathbf{x}^{\prime} \gamma \mid \mathbf{d}=0\right)}{\operatorname{Var}\left(\Delta \mathbf{x}^{\prime} \gamma\right)}
$$

The condition stated in Equation (15) helps estimate $\mathbb{E}(\varepsilon \mid \mathbf{d}=1)-\mathbb{E}(\varepsilon \mid \mathbf{d}=0)$, which cannot be measured because $\varepsilon$ is not observed, based on estimates of $\mathbb{E}\left(\Delta \mathbf{x}^{\prime} \gamma \mid \mathbf{d}=1\right)-\mathbb{E}\left(\Delta \mathbf{x}^{\prime} \gamma \mid \mathbf{d}=0\right)$, $\operatorname{Var}\left(\Delta \mathbf{x}^{\prime} \gamma\right)$ and $\operatorname{Var}(\varepsilon)$. Thereby, we derive an estimate of the bias induced by the selection process based on the following formula:

$$
\widehat{\operatorname{bias}}=\frac{\widehat{\operatorname{Var}}(\mathbf{d})}{\widehat{\operatorname{Var}}(\vartheta)} \times \frac{\hat{\mathbb{E}}\left(\Delta \mathbf{x}^{\prime} \hat{\gamma} \mid \mathbf{d}=1\right)-\hat{\mathbb{E}}\left(\Delta \mathbf{x}^{\prime} \hat{\gamma} \mid \mathbf{d}=0\right)}{\widehat{\operatorname{Var}}\left(\Delta \mathbf{x}^{\prime} \hat{\gamma}\right)} \times \widehat{\operatorname{Var}}(\hat{\varepsilon})
$$

Table 7 shows estimates of the bias that could result from unobservable change that could simultaneously affect issuance of land certificates and time allocated to farming activities. For comparison we have restricted the sample to the common support. Column (1) reports the mean of main outcomes of this study for treated households. Column (2) shows semiparametric difference-in-difference estimates of the ATT. In Column (3) we estimate the effect 
Table 7: Quantifying the Relative Importance of Selection on Unobservables.

\begin{tabular}{|c|c|c|c|c|c|}
\hline Outcomes & $\begin{array}{c}\text { Average } \\
\text { (1) }\end{array}$ & $\begin{array}{c}\hat{\alpha} \\
\mathrm{ABD} \\
(2)\end{array}$ & $\begin{array}{l}\hat{\alpha} \\
\text { OLS } \\
(3)\end{array}$ & $\begin{array}{c}\text { Bias } \\
(4)\end{array}$ & $\begin{array}{l}\text { Implied } \\
\text { ratio } \\
(5)\end{array}$ \\
\hline Child labor & $\begin{array}{l}15.323 \\
(1.897)\end{array}$ & $\begin{array}{r}3.755 \\
(2.632)\end{array}$ & $\begin{array}{c}3.482^{*} \\
(1.783)\end{array}$ & -9.664 & -2.775 \\
\hline - Girls & $\begin{array}{r}4.491 \\
(0.794)\end{array}$ & $\begin{array}{r}1.205 \\
(1.317)\end{array}$ & $\begin{array}{r}0.378 \\
(0.746)\end{array}$ & 1.922 & 5.080 \\
\hline - Boys & $\begin{array}{l}10.832 \\
(1.479)\end{array}$ & $\begin{array}{r}2.551 \\
(2.736)\end{array}$ & $\begin{array}{c}3.104^{* *} \\
(1.513)\end{array}$ & -11.925 & -3.842 \\
\hline Adult labor & $\begin{array}{r}135.540 \\
(7.758)\end{array}$ & $\begin{array}{r}-12.042 \\
(7.917)\end{array}$ & $\begin{array}{l}-26.703^{* * *} \\
(7.511)\end{array}$ & -2.832 & 0.106 \\
\hline - Women & $\begin{array}{l}46.854 \\
(2.855)\end{array}$ & $\begin{array}{r}1.450 \\
(3.178)\end{array}$ & $\begin{array}{r}-2.162 \\
(2.754)\end{array}$ & -2.503 & 1.157 \\
\hline - Men & $\begin{array}{l}88.686 \\
(5.142)\end{array}$ & $\begin{array}{l}-13.492^{* *} \\
(5.832)\end{array}$ & $\begin{array}{l}-24.540^{* * *} \\
(5.379)\end{array}$ & -1.507 & 0.061 \\
\hline Hired labor & $\begin{array}{r}1.342 \\
(0.280)\end{array}$ & $\begin{array}{l}1.181^{* * *} \\
(0.336)\end{array}$ & $\begin{array}{c}0.984^{* *} \\
(0.446)\end{array}$ & 15.713 & 15.971 \\
\hline Land size ploughed (ha) & $\begin{array}{r}2.191 \\
(0.125)\end{array}$ & $\begin{array}{r}0.180 \\
(0.140)\end{array}$ & $\begin{array}{r}0.143 \\
(0.098)\end{array}$ & 0.998 & 6.972 \\
\hline Number of households & 161 & 591 & 591 & 591 & 591 \\
\hline
\end{tabular}

Note: Column (1) reports the average level of the outcome as measured among the households with a land certificate by June 2006. Column (2) shows estimates of the ATT using the semi-parametric difference-indifference estimator. Column (3) shows the effect of the land certificate measured with an OLS specification. The model tested is $\Delta \mathbf{y}=\alpha \cdot \mathbf{d}+\Delta \mathbf{x}^{\prime} \gamma+\varepsilon$, where $\Delta \mathbf{y}$ (respectively $\Delta \mathbf{x}$ ) represents the change of outcome $\mathbf{y}$ (respectively household and landholding characteristics) between the meher 2006-07 and 1998-99. d is a binary variable equal to 1 if the household has received its land certificate ahead of the meher 2006-07 and 0 otherwise and $\varepsilon$ represents unobservable changes that determine change in outcomes. Column (4) shows the estimates of the bias induced by unobservables changes that affect issuance of land certificates and the outcome of interest. Column (5) compares the size of bias to that of the OLS estimates. Standard errors are in parentheses. They are estimated without accounting for clustering at the kebele level. Significance levels are denoted as follows: ${ }^{*} \mathrm{p}<0.10,{ }^{* *} \mathrm{p}<0.05,{ }^{* * *} \mathrm{p}<0.01$.

of the land certificate based on Equation (12). ${ }^{28}$ The coefficients reported in Column (4) are estimates of the bias specified in Equation (16). Column (5) compares the size of the bias to that of the treatment effect reported in Column (3).

For most outcomes, the results of Table 7 suggest that the size of bias produced by unobservable changes could confound the treatment effect. However, the potential bias that unobservable change of household characteristics which are correlated to issuance of land certificate can induce on labour supply of male adult members is estimated at -1.5 person days. This is not enough to confound the ATT estimate of -13.49 person-days of the semi-parametric differencein-difference estimate nor the -24.54 person days reported by the OLS estimates. Overall it seems unlikely that the unobservable characteristics correlated to issuance of land certificate

\footnotetext{
${ }^{28}$ The time varying observable characteristics considered include gender and age of household head, number of adult members, number of children, possession of a pair of oxen, type of roof of the homestead, amount of land controlled by the household, soil quality proxied by slope, and distance to the nearest town.
} 
could induce a reduction of labour supply by male adult members similar to that found in this study. Conversely, the change in labour supply of hired workers can be explained by unobservable heterogeneity correlated to issuance of land certificates. 


\section{Conclusion}

In the aftermath of a land reform in 1975 in Ethiopia, land was nationalized and every person was entitled to a piece of land conditional on self-cultivation and permanent physical presence in a location. Peasant associations were created at the local level to enforce those rules. They carried out periodic land redistributions to accommodate the demand from landless households and maintain an egalitarian land distribution across households. As tenure insecurity rose in response to increased demand for land so did the pressure for new land reforms. New laws were introduced to allow land registration programmes, give legal recognition to land rights and shift the burden of land right protection and enforcement to the State.

Several papers studying land related issues in Ethiopia argue that the threat of land loss through land redistribution by the peasant associations increased land tenure insecurity and reduced the incentives on the part of holders to invest in their land and to manage it properly. This paper shows that land tenure insecurity is also associated with land boundary disputes between landholders with neighbouring plots and distorts time allocation toward pre-planting activities. Indeed, Belay (2010) reports that land boundary disputes are the most common reason of land disputes in Amhara. Moreover, studying the land registration programme in Amhara, Adenew and Abdi (2005) reports that plot boundary demarcation using white stones as boundary markers was advantageous as they prevent other landholders from constantly push the boundaries of their plots during ploughing.

The study is based on household panel data collected before and after a land registration programme was implemented in Amhara between 2003 and 2010. We find that time allocated to farming activities during pre-planting decreased for households whose land have received their land certificates on time for the agricultural season. The estimates show that male adults in households that completed the land registration activities on time decreased the amount of time allocated to farming activities by at least $13.5 \%$. We show that the reduction of labour supply is not driven by a reduction of land size cultivated and is higher for households whose landholdings are fragmented into several disjunct plots. Considering the results of Deininger et al. (2011) on investment, the results of this study suggest that households with a land certificates were likely to invest some of the time freed to building and repairing soil and water conservation infrastructures. Labour supply by female members remained unchanged whereas labour by male children has slightly increased. Moreover, the land registration programme is 
associated with an increase of labour supply by hired workers and therefore might have some positive externality on other households.

The findings of this paper contribute to the growing literature on the endogenous production of tenure security by households (Besley, 1995; Brasselle et al., 2002; de Janvry et al., 2015; Field, 2007; Goldstein and Udry, 2008). We show that in absence of formal demarcation and registration of their landholdings, households spend time on their plots to prevent encroachment. The results of this study are, however, observed in a context where land size per adult member is relatively small and households landholdings are fragmented. Land market is also restricted and peasant associations use land reallocation as a means to balance "availability" and demand for land at the community level. The external validity of these results is therefore likely limited. 


\section{Bibliography}

Abadie, A., 2005. "Semiparametric Difference-in-Differences Estimators." Review of Economic Studies 72(1), $1-19$.

Abadie, A. and Imbens, G. W., 2006. "Large Sample Properties of Matching Estimators for Average Treatment Effects." Econometrica 74(1), 235-267.

—, 2008. "On the Failure of the Bootstrap for Matching Estimators." Econometrica 76(6), 15371557.

—, 2011. "Bias-Corrected Matching Estimators for Average Treatment Effects." Journal of Business $\mathcal{E}$ Economic Statistics 29(1), 1-11.

—, 2016. "Matching on the Estimated Propensity Score." Econometrica 84(2), 781-807.

Adal, Y., 2002. "Review of Landholding Systems and Policies in Ethiopia Under the Different Regimes." Working Paper 5/2002, EEA/Ethiopian Economic Policy Research institute.

Adenew, B. and Abdi, F., 2005. "Land Registration in Amhara Region, Ethiopia." Tech. Rep., IIED (International Institute for Environment and Development).

Ali, D. A., Dercon, S., and Gautam, M., 2007. "Property Rights in a Very Poor Country : Tenure Insecurity and Investment in Ethiopia." Policy Research Working Paper Series 4363, The World Bank.

Altonji, J. G., Elder, T. E., and Taber, C. R., 2005. "Selection on Observed and Unobserved Variables: Assessing the Effectiveness of Catholic Schools." Journal of Political Economy 113(1), 151-184.

ARD, I., 2004. "Ethiopia Land Policy and Administration Assessment." Tech. Rep., USAID, United States Agency for International Development, Burlington, USA.

Belay, A., 2010. The Effects of Rural Land Certification in Securing Land Rights : A Case of Amhara Region, Ethiopia. Enschede: [University of Twente]. International Institute for GeoInformation Science and Earth Observation (ITC).

Benin, S. and Pender, J., 2001. "Impacts of Land Redistribution on Land Management and Productivity in the Ethiopian Highlands." Land Degradation \& Development 12(6), 555 - 568.

Besley, T., 1995. "Property Rights and Investment Incentives: Theory and Evidence from Ghana." Journal of Political Economy 103(5), 903-37.

Besley, T. and Ghatak, M., 2010. Property Rights and Economic Development, vol. 5 of Handbook of Development Economics, chap. 0. Elsevier, pages 4525-4595.

Bezabih, M., Kohlin, G., and Mannberg, A., 2011. "Trust, Tenure Insecurity, and Land Certification in Rural Ethiopia." Journal of Socio-Economics 40(6), 833 - 843. 
Brasselle, A.-S., Gaspart, F., and Platteau, J.-P., 2002. "Land Tenure Security and Investment Incentives: Puzzling Evidence from Burkina Faso." Journal of Development Economics 67(2), 373-418.

Bruce, J. W., Hoben, A., and Rahmato, D., 1994. After the Derg: An Assessment of Rural Land Tenure Issues in Ethiopia. Land Tenure Center, University of Wisconsin-Madison.

Cameron, A. C. and Miller, D. L., 2015. "A Practitioner's Guide to Cluster-Robust Inference." Journal of Human Resources 50(2), 317-372.

Crewett, W., Bogale, A., and Korf, B., 2008. "Land Tenure in Ethiopia: Continuity and Change, Shifting Rulers, and the Quest for State Control." CAPRi working papers 91, International Food Policy Research Institute (IFPRI).

Crewett, W. and Korf, B., 2008. “Ethiopia: Reforming Land Tenure." Review of African Political Economy 35(116), 203 - 220.

de Janvry, A., Emerick, K., Gonzalez-Navarro, M., and Sadoulet, E., 2015. “Delinking Land Rights from Land Use: Certification and Migration in Mexico." American Economic Review 105(10), 3125-49.

Deininger, K., Ali, D. A., and Alemu, T., 2011. "Impacts of Land Certification on Tenure Security, Investment, and Land Market Participation: Evidence from Ethiopia." Land Economics 87(2), 312-334.

Deininger, K. and Jin, S., 2006. "Tenure security and land-related investment: Evidence from Ethiopia." European Economic Review 50(5), 1245-1277.

Devereux, S. and Guenther, B., 2007. “Social Protection and Agriculture in Ethiopia.” Working Paper, Institute of Development Studies, University of Sussex.

Ege, S., 1997. "The Promised Land: the Amhara Land Redistribution of 1997." Working Papers on Ethiopian Development 12, Norwegian University of Trondheim.

Field, E., 2007. "Entitled to Work: Urban Property Rights and Labor Supply in Peru." The Quarterly Journal of Economics 122(4), 1561-1602.

Getahun, A., 2006. "Information System for Land Administration: Experiences in the Amhara Region." In "Standardization of Rural Land Registration and Cadastral Surveying Methodologies : Experiences in Ethiopia," pages 299 - 314.

Goldstein, M. and Udry, C., 2008. "The Profits of Power: Land Rights and Agricultural Investment in Ghana." Journal of Political Economy 116(6), 981-1022.

Holden, S. and Yohannes, H., 2002. "Land Redistribution, Tenure Insecurity, and Intensity of Production: A Study of Farm Households in Southern Ethiopia." Land Economics 78(4), 573 590.

Rahmato, D., 1994. "Land Policy in Ethiopia at the Crossroads." In "In Land Tenure and Land Policy after the Derg: Proceedings of the Second Workshop of the Land Tenure Project," , edited by Rahmato, D. Trondieim: University of Trondieim. 
—, 2004. "Searching for Tenure Security? The Land System and New Policy Initiatives in Ethiopia." Discussion Paper 12, Forum for Social Studies, Addis Ababa.

Rubin, D. B., 1974. "Estimating Causal Effects of Treatments in Randomized and Nonrandomized Studies." Journal of Educational Psychology 66(5), 688-701.

SARDP, 2010. Building Ethiopia's Future: The Sida-Amhara Rural Development Programme. Bahir Dar, Ethiopia: Sida-Amhara Rural Development Programme (SARDP).

SARDP and BoEPLAU, 2010. "Land Registration and Certification: Experiences from the Amhara National Regional State in Ethiopia." Available from SARDP Web site: http://www.sida.se/globalassets/global/countries-and-regions/ africa/kenya/ethiopia_amhara_final.pdf. Accessed: 2014-10-25.

Tegegne, H. M., 2009. “Rethinking Property and Society in Gond?rine Ethiopia." African Studies Review 52(3), 89 - 106.

Tegnäs, B., Poluha, E., Johnson, S., Demissie, S., and Mandefro, Y. F., 2009. "Sida-Amhara Rural Development Programme 1997-2008." Review 08, Swedish International Development Cooperation Agency, Stockholm, Sweden. 


\section{List of Tables}

1 Descriptive Statistics of Households in 1999. . . . . . . . . . . . . . . . . 14

2 Households Characteristics in 1999 and 2002 by Treatment Status. . . . . . . . . . 18

3 Impact of Land Registration on the Treated Before 2007. . . . . . . . . . . . . . 23

4 Impact of Land Registration on the Treated during meher 2006-07. . . . . . . . . . 26

5 Impact of Land Registration by Task and Source of Labour. . . . . . . . . . . . . . 27

6 Heterogeneity of the Impact of Land Registration on Land and Time Use. . . . . 28

7 Quantifying the Relative Importance of Selection on Unobservables. . . . . . . . 32

A-1 Pattern of Attrition Across Rounds . . . . . . . . . . . . . . . . . . . 41

A-2 Marginal Effects of Household Characteristics on Attrition . . . . . . . . . . 42

A-3 Marginal Effects of Household Characteristics on Expectation of Land Loss . . 43

A-4 Household Characteristics Across kebeles in 1999. . . . . . . . . . . . . . . . 44

A-5 Marginal Effects of Household Characteristics on the Propensity Score. . . . . . . 45

A-6 Impact of Land Registration on Agricultural Input and Output . . . . . . . . . . 46

A-7 Impact of Land Registration Before 2007 Using other Matching Estimators. . . . . 47

A-8 Impact of Land Certificate on the Treated Excluding Households in Wolkie. . . . 48

\section{List of Figures}

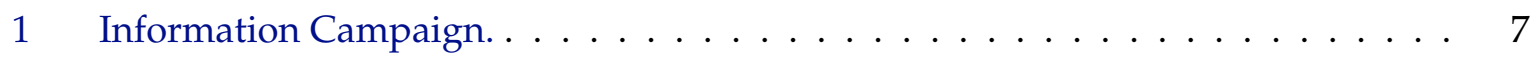

2 Land Demarcation Activities. . . . . . . . . . . . . . . . . . . . 8

3 Registration Programme per Village . . . . . . . . . . . . . . . . . . . . . 16

A-1 Map of Ethiopia with Amhara and East Gojjam. . . . . . . . . . . . . . 40

A-2 Distribution of the Propensity Scores of Treated and Untreated Households. . . . 40 


\section{Appendix}

Figure A-1: Map of Ethiopia with Amhara and East Gojjam.

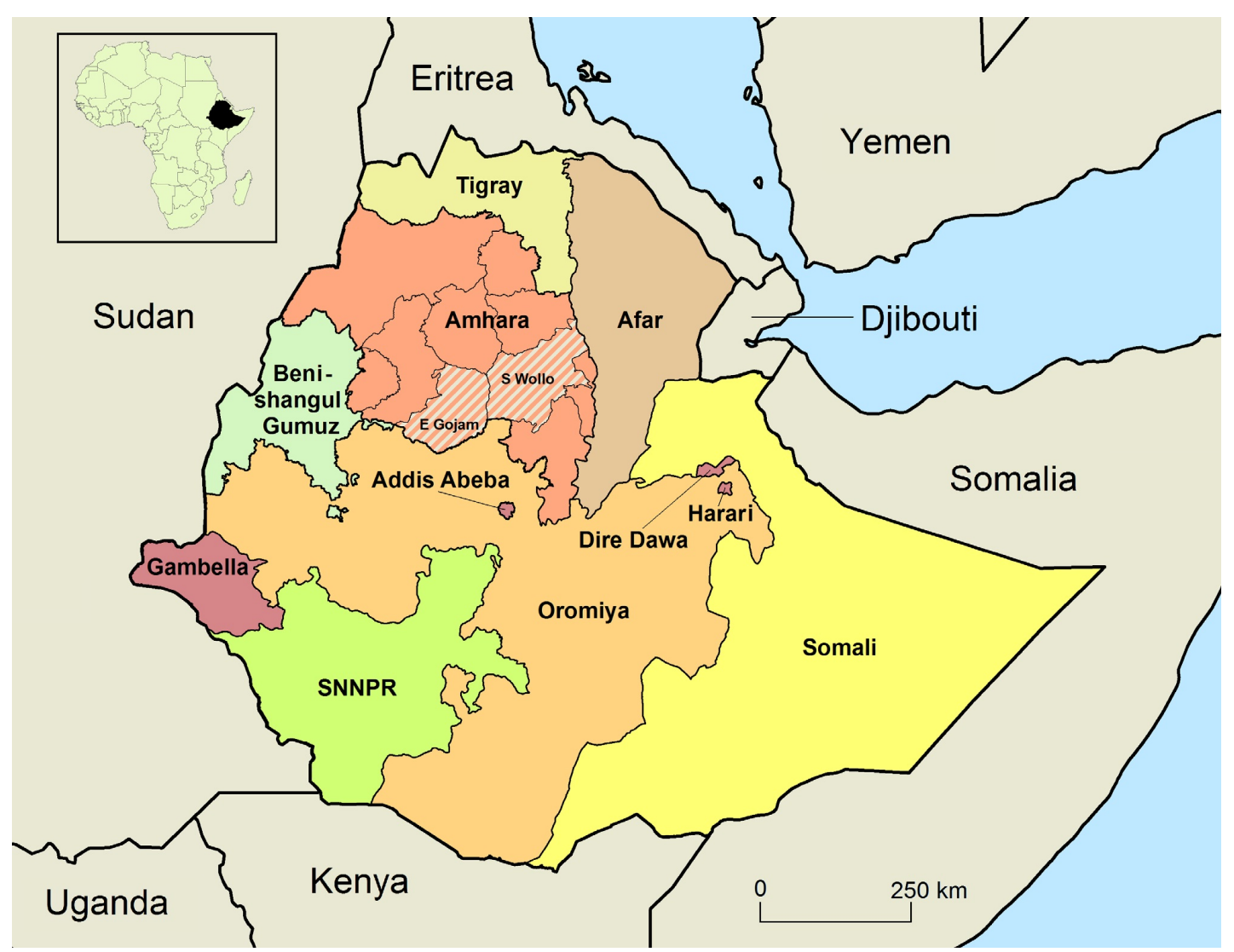

Source: Excerpt from SARDP and BoEPLAU (2010).

Figure A-2: Distribution of the Propensity Scores of Treated and Untreated Households.

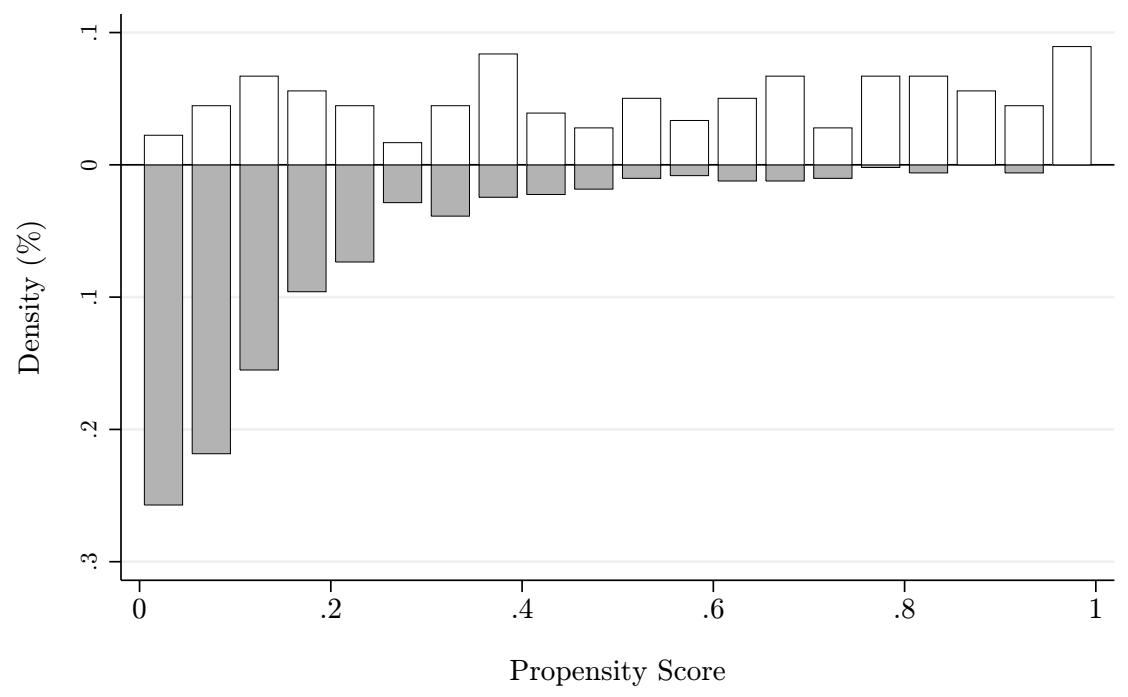


Table A-1: Pattern of Attrition Across Rounds

\begin{tabular}{|c|c|c|c|c|c|c|}
\hline \multicolumn{4}{|c|}{ Round } & \multirow{2}{*}{ Frequency } & \multirow{2}{*}{ Percentage } & \multirow{2}{*}{ Cumul } \\
\hline 1 & 2 & 3 & 4 & & & \\
\hline$\bullet$ & $\bullet$ & $\bullet$ & $\bullet$ & 669 & 93.44 & 93.44 \\
\hline$\bullet$ & O & ○ & O & 18 & 2.51 & 95.95 \\
\hline • & $\bullet$ & ○ & O & 16 & 2.23 & 98.18 \\
\hline \multirow[t]{2}{*}{$\bullet$} & - & • & O & 13 & 1.82 & 100.00 \\
\hline & & & & 716 & 100.00 & \\
\hline
\end{tabular}

Note: This table shows the attrition pattern of households across rounds. As the sample is restricted to households that were present at the baseline, we do not account for households that joined the panel at later rounds.

"๑" represents a household that was successfully surveyed at the designated round. "O" represents a household that was not observed during the

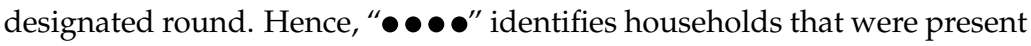

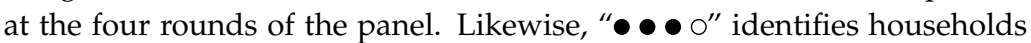
that were not surveyed in 2007 but were successfully surveyed in 2002 and 2004. 
Table A-2: Marginal Effects of Household Characteristics on Attrition

\begin{tabular}{|c|c|}
\hline & Attrition \\
\hline Female headed $\mathrm{hh}^{\dagger}$ & $\begin{array}{l}0.0016 \\
(0.012)\end{array}$ \\
\hline Age of hh head (yrs) & $\begin{array}{r}-0.0002 \\
(0.000)\end{array}$ \\
\hline HH head is literate ${ }^{\dagger}$ & $\begin{array}{l}0.0079 \\
(0.007)\end{array}$ \\
\hline Household size & $\begin{array}{c}-0.0001 \\
(0.002)\end{array}$ \\
\hline Number of oxen & $\begin{array}{c}0.0049 \\
(0.004)\end{array}$ \\
\hline $\mathrm{HH}_{\text {main activity: farming }}^{\dagger}$ & $\begin{array}{l}0.0052 \\
(0.009)\end{array}$ \\
\hline Homestead with iron sheets roof ${ }^{\dagger}$ & $\begin{array}{l}0.0020 \\
(0.007)\end{array}$ \\
\hline Distance homestead-town (mins) & $\begin{array}{r}-0.0002 \\
(0.000)\end{array}$ \\
\hline Total land size (ha) & $\begin{array}{r}-0.0077 \\
(0.009)\end{array}$ \\
\hline HH has a sloped land ${ }^{\dagger}$ & $\begin{array}{l}0.0017 \\
(0.006)\end{array}$ \\
\hline Livestock (log US \$) & $\begin{array}{r}-0.0055 \\
(0.004)\end{array}$ \\
\hline Off-farm income (log US \$) & $\begin{array}{r}-0.0023 \\
(0.002)\end{array}$ \\
\hline \multicolumn{2}{|l|}{$\mathrm{HH}$ expects change of land size $\mathrm{e}^{\dagger}$} \\
\hline - HH expects land gain & $\begin{array}{r}0.0020 \\
(0.008)\end{array}$ \\
\hline - HH expects land loss & $\begin{array}{r}0.0063 \\
(0.010)\end{array}$ \\
\hline \multicolumn{2}{|c|}{ Household labor supply in person-days: } \\
\hline - Child labor & $\begin{array}{c}0.0001 \\
(0.000)\end{array}$ \\
\hline - Adult labor & $\begin{array}{r}-0.0001 \\
(0.000)\end{array}$ \\
\hline Debo labor & $\begin{array}{c}0.0003 \\
(0.000)\end{array}$ \\
\hline Hired labor & $\begin{array}{l}0.0005 \\
(0.001)\end{array}$ \\
\hline Land size plough (ha) & $\begin{array}{r}-0.0048 \\
(0.013)\end{array}$ \\
\hline Number of households & 716 \\
\hline $\mathbb{P}($ attrition $=1)$ & 0.066 \\
\hline LR Test & 0.000 \\
\hline
\end{tabular}

${ }^{\dagger}$ Indicates dummy variables.

Robust standard errors in parentheses. Significance levels are denoted as follows: ${ }^{*} \mathrm{p}<0.10,{ }^{* *} \mathrm{p}<0.05,{ }^{* * *} \mathrm{p}<0.01$. 
Table A-3: Marginal Effects of Household Characteristics on Expectation of Land Loss

\begin{tabular}{|c|c|c|c|c|}
\hline & 1999 & 2002 & 2004 & 2007 \\
\hline \multirow[t]{2}{*}{ Female headed $\mathrm{hh}^{\dagger}$} & -0.014 & -0.029 & -0.031 & -0.019 \\
\hline & $(0.054)$ & $(0.046)$ & $(0.040)$ & $(0.050)$ \\
\hline \multirow[t]{2}{*}{ Age of hh head (yrs) } & 0.000 & 0.001 & $0.002^{* *}$ & 0.001 \\
\hline & $(0.001)$ & $(0.001)$ & $(0.001)$ & $(0.001)$ \\
\hline \multirow[t]{2}{*}{$\mathrm{HH}$ head is literate ${ }^{\dagger}$} & 0.001 & $0.051^{* *}$ & $0.048^{* *}$ & 0.056 \\
\hline & $(0.033)$ & $(0.025)$ & $(0.024)$ & $(0.036)$ \\
\hline \multirow[t]{2}{*}{ Household size } & 0.006 & -0.001 & -0.005 & 0.001 \\
\hline & $(0.009)$ & $(0.006)$ & $(0.006)$ & $(0.008)$ \\
\hline \multirow[t]{2}{*}{ Distance homestead-town (mins) } & 0.000 & -0.000 & -0.000 & 0.000 \\
\hline & $(0.000)$ & $(0.000)$ & $(0.000)$ & $(0.000)$ \\
\hline \multirow[t]{2}{*}{ Homestead with iron sheets roof ${ }^{\dagger}$} & 0.048 & $0.050^{* *}$ & $0.059^{* *}$ & -0.011 \\
\hline & $(0.032)$ & $(0.025)$ & $(0.024)$ & $(0.050)$ \\
\hline \multirow[t]{2}{*}{ Number of oxen } & 0.011 & $-0.022^{*}$ & 0.016 & -0.001 \\
\hline & $(0.014)$ & $(0.012)$ & $(0.012)$ & $(0.014)$ \\
\hline \multirow[t]{2}{*}{ Land size (ha) } & $0.122^{* * *}$ & $0.084^{* * *}$ & $0.027^{* *}$ & $0.035^{*}$ \\
\hline & $(0.025)$ & $(0.023)$ & $(0.012)$ & $(0.019)$ \\
\hline Number of households & 669 & 669 & 669 & 669 \\
\hline $\mathbb{P}(\mathbf{y}=1)$ & 0.211 & 0.205 & 0.223 & 0.256 \\
\hline LR Test & 0.000 & 0.000 & 0.000 & 0.243 \\
\hline
\end{tabular}

Note: This table reports the marginal effects of different household characteristics on the probability that a household expects a land loss over the next 5 years through land reallocation and redistribution by the peasant association. Robust standard errors are in parentheses and significance levels are denoted as follows: ${ }^{*} \mathrm{p}<0.10$, ${ }^{* *} \mathrm{p}<0.05,{ }^{* * *} \mathrm{p}<0.01$.

${ }^{\dagger}$ Indicates dummy variables. 
Table A-4: Household Characteristics Across kebeles in 1999.

\begin{tabular}{|c|c|c|c|c|c|c|}
\hline \multirow{2}{*}{ Variables } & \multicolumn{4}{|c|}{ Certificate Issued } & \multicolumn{2}{|c|}{ No Certificate } \\
\hline & Amanuel & D. Elias & Kebi & Telma & Wolkie & S. Debir \\
\hline \multicolumn{7}{|l|}{ Panel A: Household characteristics } \\
\hline Female headed $\mathrm{hh}^{\dagger}$ & 0.09 & 0.11 & 0.15 & 0.09 & 0.09 & 0.15 \\
\hline Age of hh head (yrs) & 44.12 & 45.72 & 48.22 & 42.13 & 43.97 & 43.30 \\
\hline $\mathrm{HH}$ head is literate ${ }^{\dagger}$ & 0.46 & 0.49 & 0.29 & 0.44 & 0.39 & 0.43 \\
\hline Household size & 5.21 & 6.02 & 5.55 & 4.68 & 5.22 & 4.55 \\
\hline Number of oxen & 1.77 & 2.42 & 1.87 & 1.00 & 1.00 & 1.00 \\
\hline $\mathrm{HH}$ main activity: farming ${ }^{\dagger}$ & 0.91 & 0.83 & 0.87 & 0.91 & 0.86 & 0.88 \\
\hline Homestead with iron sheets roof ${ }^{\dagger}$ & 0.54 & 0.69 & 0.67 & 0.69 & 0.33 & 0.53 \\
\hline Distance homestead-town (mins) & 40.55 & 36.24 & 75.66 & 90.94 & 93.89 & 67.63 \\
\hline Total land size (ha) & 1.35 & 1.75 & 1.70 & 1.08 & 1.35 & 1.04 \\
\hline Land size per aeu (ha) ${ }^{1}$ & 0.35 & 0.38 & 0.39 & 0.29 & 0.36 & 0.31 \\
\hline Livestock $(\$)^{2}$ & 1120.12 & 1476.71 & 1136.68 & 635.25 & 637.17 & 567.70 \\
\hline Off-farm income (\$) & 47.77 & 96.96 & 51.06 & 26.29 & 112.28 & 84.89 \\
\hline
\end{tabular}

Panel B: Land tenure security over the next 5 years

$\begin{array}{lllllll}\text { HH expects change of land size }{ }^{\dagger} & 0.79 & 0.75 & 0.87 & 0.68 & 0.82 & 0.65 \\ \text { - HH expects land gain } & 0.60 & 0.49 & 0.53 & 0.56 & 0.61 & 0.52 \\ \text { - HH expects land loss } & 0.20 & 0.25 & 0.34 & 0.13 & 0.21 & 0.13\end{array}$

\section{Panel C: Land use and labour supply in person-day}

$\begin{array}{lrrrrrr}\text { Household labour } & 166.64 & 195.37 & 117.44 & 69.89 & 68.09 & 72.88 \\ \text { - Children } & 9.24 & 17.14 & 2.56 & 2.38 & 0.91 & 0.78 \\ \text { - Adults } & 157.41 & 178.23 & 114.88 & 67.51 & 67.19 & 72.10 \\ \text { Debo workers } & 5.22 & 10.50 & 7.14 & 7.70 & 0.35 & 13.19 \\ \text { Hired workers } & 0.00 & 0.39 & 0.00 & 0.28 & 0.01 & 4.11 \\ \text { Land size plough (ha) } & 1.21 & 1.74 & 1.45 & 1.01 & 0.87 & 1.06\end{array}$

Panel D: Possession of a land certificate in June 2006

\begin{tabular}{lcccccc} 
No Certificate & 0.09 & 0.06 & 0.53 & 0.09 & 1.00 & 1.00 \\
$\begin{array}{l}\text { Has a certificate } \\
\quad \text { - temporary }\end{array}$ & & & & & & \\
$\quad$ - primary & 0.31 & 0.11 & 0.42 & 0.80 & 0.00 & 0.00 \\
\hline \# Households & 0.60 & 0.82 & 0.05 & 0.11 & 0.00 & 0.00 \\
\hline \hline
\end{tabular}

${ }^{\dagger}$ Indicates dummy variables.

1 aeu stands for adult equivalent unit. It attributes different sizes to household members with respect to age and gender as follows: male 15 years or older $=1$, female 15 years or older $=0.8$, male or female 14 years or under $=$ 0.5 .

2 Prices are converted in 2005 international \$ using the consumer prices indexes and the purchasing power parity conversion factor for private consumption in international dollars collected from the World Development Indicators (WDI).

${ }^{3}$ Temporary certificates are issued after land demarcation in presence of the neighbours and after verification with the land use and administration committee. It is not a legal document yet. The parcels listed on the temporary certificate are publicly debated. In case of agreement and after corrections the primary certificate are issued and the temporary certificates destroyed. Most of the households holding a temporary certificate are waiting for their primary certificate to be issued. 
Table A-5: Marginal Effects of Household Characteristics on the Propensity Score.

\begin{tabular}{|c|c|c|c|c|}
\hline & (1) & (2) & (3) & (4) \\
\hline Female headed $\mathrm{hh}^{\dagger}$ & $\begin{array}{l}0.190^{* * *} \\
(0.053)\end{array}$ & $\begin{array}{l}0.279^{* * *} \\
(0.067)\end{array}$ & $\begin{array}{c}0.130^{*} \\
(0.070)\end{array}$ & $\begin{array}{l}0.297^{* * *} \\
(0.070)\end{array}$ \\
\hline Age of hh head (yrs) & $\begin{array}{r}-0.000 \\
(0.001)\end{array}$ & $\begin{array}{r}-0.002 \\
(0.002)\end{array}$ & $\begin{array}{r}-0.001 \\
(0.001)\end{array}$ & $\begin{array}{r}-0.002 \\
(0.002)\end{array}$ \\
\hline $\mathrm{HH}$ rented-in/out land ${ }^{\dagger}$ & $\begin{array}{r}0.055 \\
(0.041)\end{array}$ & $\begin{array}{r}0.093 \\
(0.059)\end{array}$ & $\begin{array}{r}0.049 \\
(0.039)\end{array}$ & $\begin{array}{c}0.104^{*} \\
(0.060)\end{array}$ \\
\hline HH has a pair of oxen ${ }^{\dagger}$ & $\begin{array}{r}0.025 \\
(0.041)\end{array}$ & $\begin{array}{r}-0.058 \\
(0.070)\end{array}$ & $\begin{array}{l}-0.027 \\
(0.038)\end{array}$ & $\begin{array}{r}-0.062 \\
(0.073)\end{array}$ \\
\hline Homestead with iron sheets roof ${ }^{\dagger}$ & $\begin{array}{r}0.019 \\
(0.039)\end{array}$ & $\begin{array}{r}0.053 \\
(0.062)\end{array}$ & $\begin{array}{r}0.028 \\
(0.033)\end{array}$ & $\begin{array}{r}0.065 \\
(0.064)\end{array}$ \\
\hline Number of children & $\begin{array}{r}0.010 \\
(0.012)\end{array}$ & $\begin{array}{l}-0.021 \\
(0.020)\end{array}$ & $\begin{array}{r}-0.012 \\
(0.012)\end{array}$ & $\begin{array}{r}-0.024 \\
(0.021)\end{array}$ \\
\hline Number of adults & $\begin{array}{l}-0.004 \\
(0.015)\end{array}$ & $\begin{array}{l}-0.019 \\
(0.026)\end{array}$ & $\begin{array}{l}-0.007 \\
(0.013)\end{array}$ & $\begin{array}{r}-0.019 \\
(0.027)\end{array}$ \\
\hline Land size (ha) & $\begin{array}{r}0.052 \\
(0.036)\end{array}$ & $\begin{array}{r}0.056 \\
(0.047)\end{array}$ & $\begin{array}{r}0.028 \\
(0.028)\end{array}$ & $\begin{array}{r}0.057 \\
(0.049)\end{array}$ \\
\hline $\mathrm{HH}_{\text {has a sloped land }}^{\dagger}$ & $\begin{array}{r}-0.072 \\
(0.047)\end{array}$ & $\begin{array}{l}-0.121^{* *} \\
(0.059)\end{array}$ & $\begin{array}{l}-0.061 \\
(0.045)\end{array}$ & $\begin{array}{l}-0.134^{* *} \\
(0.059)\end{array}$ \\
\hline $\mathrm{HH}_{\text {has }}$ an irrigated land ${ }^{\dagger}$ & $\begin{array}{r}0.055 \\
(0.047)\end{array}$ & $\begin{array}{r}0.033 \\
(0.096)\end{array}$ & $\begin{array}{r}0.009 \\
(0.043)\end{array}$ & $\begin{array}{r}0.013 \\
(0.105)\end{array}$ \\
\hline $\mathrm{HH}_{\text {used improved seed }}^{\dagger}$ & $\begin{array}{l}0.106^{* *} \\
(0.045)\end{array}$ & $\begin{array}{r}0.096 \\
(0.076)\end{array}$ & $\begin{array}{r}0.040 \\
(0.038)\end{array}$ & $\begin{array}{r}0.081 \\
(0.081)\end{array}$ \\
\hline $\mathrm{HH}_{\text {used modern fertilizer }}^{\dagger}$ & $\begin{array}{r}0.051 \\
(0.051)\end{array}$ & $\begin{array}{l}-0.001 \\
(0.076)\end{array}$ & $\begin{array}{r}-0.008 \\
(0.037)\end{array}$ & $\begin{array}{l}-0.022 \\
(0.081)\end{array}$ \\
\hline $\mathrm{HH}$ is multicroping ${ }^{\dagger}$ & $\begin{array}{r}0.070 \\
(0.051)\end{array}$ & $\begin{array}{r}0.064 \\
(0.067)\end{array}$ & $\begin{array}{r}0.029 \\
(0.036)\end{array}$ & $\begin{array}{r}0.066 \\
(0.070)\end{array}$ \\
\hline Land size allocated to teff (ha) & $\begin{array}{r}-0.025 \\
(0.043)\end{array}$ & $\begin{array}{r}-0.051 \\
(0.075)\end{array}$ & $\begin{array}{r}-0.030 \\
(0.039)\end{array}$ & $\begin{array}{r}-0.064 \\
(0.074)\end{array}$ \\
\hline Grew oilseeds $^{\dagger}$ & $\begin{array}{l}0.125^{* *} \\
(0.052)\end{array}$ & $\begin{array}{l}0.139^{* *} \\
(0.062)\end{array}$ & $\begin{array}{r}0.066 \\
(0.047)\end{array}$ & $\begin{array}{l}0.142^{* *} \\
(0.064)\end{array}$ \\
\hline Distance homestead-town (mins) & $\begin{array}{l}-0.004^{* *} \\
(0.002)\end{array}$ & $\begin{array}{l}-0.006^{* * *} \\
(0.002)\end{array}$ & $\begin{array}{r}-0.003 \\
(0.002)\end{array}$ & $\begin{array}{l}-0.006^{* * *} \\
(0.002)\end{array}$ \\
\hline \multicolumn{5}{|l|}{ Household has a member in : } \\
\hline - the kebele administration & & & $\begin{array}{r}-0.040 \\
(0.038)\end{array}$ & \\
\hline - social court & & & $\begin{array}{r}0.113 \\
(0.070)\end{array}$ & \\
\hline - a political party & & & $\begin{array}{r}0.039 \\
(0.040)\end{array}$ & \\
\hline - a religious group & & & $\begin{array}{r}0.043 \\
(0.047)\end{array}$ & \\
\hline - a micro-insurance group & & & $\begin{array}{r}0.055 \\
(0.037)\end{array}$ & \\
\hline Household score of social capital in 2002 & & & & $\begin{array}{c}0.064^{* *} \\
(0.029)\end{array}$ \\
\hline Size & 669 & 669 & 669 & 669 \\
\hline Includes time use for meher 1998-99: & No & Yes & Yes & Yes \\
\hline $\mathbb{P}(\mathbf{d}=1)$ & 0.27 & 0.27 & 0.27 & 0.27 \\
\hline
\end{tabular}

Note: The table shows the marginal effects of household characteristics on the probability of receiving a land certificate by June 2006. We run three logit specifications using various sets of household characteristics. In (1) households characteristics are observed at the baseline in 1999. In column (2) the specification includes the same characteristics as those in (1) and time allocated to farming activities by children, household members and non-household members in 1999. From 2002 onwards, the questionnaire includes various questions about the social and political capital of household members. In column (3) the specification is the same as that in (2) and includes various measures of socio-political capital measured at round 2 in 2002. In column (4) the specification is the same as that in (2) and includes a score measuring the number of social and political groups to which the household members were connected to in 2002. The score varies from 0 to 5 .

The reference individual used for estimating the marginal effect has " 0 " as value for each dummy variable and sample mean for the continuous variables. Robust standard errors are reported in parentheses and significance levels are denoted as follows: ${ }^{*} \mathrm{p}<0.10,{ }^{* *} \mathrm{p}<0.05,{ }^{* * *} \mathrm{p}<0.01$

${ }^{\dagger}$ Indicates dummy variables. 
Table A-6: Impact of Land Registration on Agricultural Input and Output

\begin{tabular}{|c|c|c|c|c|c|c|}
\hline \multirow{2}{*}{ Outcomes } & \multicolumn{2}{|c|}{ meher 2001-02 } & \multicolumn{2}{|c|}{ meher 2003-04 } & \multicolumn{2}{|c|}{ meher 2006-07 } \\
\hline & $\begin{array}{c}\text { Average } \\
\text { (1) }\end{array}$ & $\begin{array}{c}\mathrm{ABD} \\
(2)\end{array}$ & $\begin{array}{c}\text { Average } \\
\text { (3) }\end{array}$ & $\begin{array}{c}\text { ABD } \\
(4)\end{array}$ & $\begin{array}{c}\text { Average } \\
\text { (5) }\end{array}$ & $\begin{array}{c}\mathrm{ABD} \\
(6)\end{array}$ \\
\hline Output in $\log \mathrm{kg}$ & $\begin{array}{r}6.863 \\
(0.154)\end{array}$ & $\begin{array}{r}0.222 \\
(0.202)\end{array}$ & $\begin{array}{r}6.940 \\
(0.174)\end{array}$ & $\begin{array}{r}0.270 \\
(0.238)\end{array}$ & $\begin{array}{r}7.000 \\
(0.175)\end{array}$ & $\begin{array}{r}0.112 \\
(0.224)\end{array}$ \\
\hline Total labour supply & $\begin{array}{r}160.543 \\
(7.521)\end{array}$ & $\begin{array}{r}6.721 \\
(8.120)\end{array}$ & $\begin{array}{r}147.379 \\
(8.369)\end{array}$ & $\begin{array}{r}-1.044 \\
(8.984)\end{array}$ & $\begin{array}{r}158.118 \\
(9.135)\end{array}$ & $\begin{array}{r}-9.674 \\
(9.221)\end{array}$ \\
\hline $\mathrm{HH}_{\text {used modern fertilizer }}^{\dagger}$ & $\begin{array}{r}0.839 \\
(0.029)\end{array}$ & $\begin{array}{r}0.030 \\
(0.029)\end{array}$ & $\begin{array}{r}0.845 \\
(0.029)\end{array}$ & $\begin{array}{r}0.050 \\
(0.034)\end{array}$ & $\begin{array}{r}0.826 \\
(0.030)\end{array}$ & $\begin{array}{r}0.035 \\
(0.032)\end{array}$ \\
\hline Land size ploughed (ha) & $\begin{array}{r}1.442 \\
(0.070)\end{array}$ & $\begin{array}{r}0.014 \\
(0.075)\end{array}$ & $\begin{array}{r}1.948 \\
(0.187)\end{array}$ & $\begin{array}{c}0.205^{*} \\
(0.121)\end{array}$ & $\begin{array}{r}2.191 \\
(0.125)\end{array}$ & $\begin{array}{r}0.180 \\
(0.140)\end{array}$ \\
\hline \multicolumn{7}{|l|}{ Land size of each crop (ha) } \\
\hline - teff & $\begin{array}{r}0.550 \\
(0.031)\end{array}$ & $\begin{array}{r}-0.006 \\
(0.041)\end{array}$ & $\begin{array}{r}0.655 \\
(0.076)\end{array}$ & $\begin{array}{r}-0.034 \\
(0.062)\end{array}$ & $\begin{array}{r}0.588 \\
(0.043)\end{array}$ & $\begin{array}{r}0.007 \\
(0.054)\end{array}$ \\
\hline - wheat & $\begin{array}{r}0.394 \\
(0.027)\end{array}$ & $\begin{array}{c}0.088^{* *} \\
(0.039)\end{array}$ & $\begin{array}{r}0.916 \\
(0.098)\end{array}$ & $\begin{array}{r}0.136 \\
(0.088)\end{array}$ & $\begin{array}{r}0.548 \\
(0.047)\end{array}$ & $\begin{array}{c}0.132^{* *} \\
(0.063)\end{array}$ \\
\hline - sorghum & $\begin{array}{r}0.208 \\
(0.017)\end{array}$ & $\begin{array}{r}-0.025 \\
(0.028)\end{array}$ & $\begin{array}{r}0.014 \\
(0.012)\end{array}$ & $\begin{array}{r}-0.043 \\
(0.028)\end{array}$ & $\begin{array}{r}0.722 \\
(0.056)\end{array}$ & $\begin{array}{r}-0.054 \\
(0.093)\end{array}$ \\
\hline - pulses & $\begin{array}{r}0.106 \\
(0.014)\end{array}$ & $\begin{array}{r}-0.018 \\
(0.026)\end{array}$ & $\begin{array}{r}0.407 \\
(0.035)\end{array}$ & $\begin{array}{l}0.140^{* * *} \\
(0.044)\end{array}$ & $\begin{array}{r}0.118 \\
(0.020)\end{array}$ & $\begin{array}{r}0.022 \\
(0.033)\end{array}$ \\
\hline - oil seeds & $\begin{array}{r}0.206 \\
(0.020)\end{array}$ & $\begin{array}{r}0.027 \\
(0.027)\end{array}$ & $\begin{array}{r}0.320 \\
(0.037)\end{array}$ & $\begin{array}{l}0.142^{* * *} \\
(0.043)\end{array}$ & $\begin{array}{r}0.213 \\
(0.026)\end{array}$ & $\begin{array}{r}0.013 \\
(0.039)\end{array}$ \\
\hline - vegetables & $\begin{array}{r}0.051 \\
(0.008)\end{array}$ & $\begin{array}{r}-0.015 \\
(0.014)\end{array}$ & $\begin{array}{r}0.026 \\
(0.007)\end{array}$ & $\begin{array}{r}-0.006 \\
(0.013)\end{array}$ & $\begin{array}{r}0.039 \\
(0.010)\end{array}$ & $\begin{array}{r}-0.009 \\
(0.016)\end{array}$ \\
\hline - fruits & $\begin{array}{r}0.003 \\
(0.002)\end{array}$ & $\begin{array}{r}-0.006 \\
(0.008)\end{array}$ & $\begin{array}{r}0.000 \\
(0.000)\end{array}$ & $\begin{array}{r}0.001 \\
(0.001)\end{array}$ & $\begin{array}{r}0.003 \\
(0.002)\end{array}$ & $\begin{array}{r}-0.000 \\
(0.003)\end{array}$ \\
\hline - spices & $\begin{array}{r}0.000 \\
(0.000)\end{array}$ & $\begin{array}{r}-0.002 \\
(0.001)\end{array}$ & $\begin{array}{r}0.001 \\
(0.001)\end{array}$ & $\begin{array}{r}-0.000 \\
(0.001)\end{array}$ & $\begin{array}{r}0.006 \\
(0.002)\end{array}$ & $\begin{array}{l}0.003^{* *} \\
(0.001)\end{array}$ \\
\hline - coffee & $\begin{array}{r}0.001 \\
(0.001)\end{array}$ & $\begin{array}{l}0.011^{* * *} \\
(0.003)\end{array}$ & $\begin{array}{r}0.002 \\
(0.001)\end{array}$ & $\begin{array}{l}0.011^{* * *} \\
(0.003)\end{array}$ & $\begin{array}{r}0.009 \\
(0.003)\end{array}$ & $\begin{array}{c}0.009^{*} \\
(0.005)\end{array}$ \\
\hline Number of households & 161 & 591 & 161 & 591 & 161 & 591 \\
\hline
\end{tabular}

Note: This table reports the estimates of the effect of land registration on agricultural output, input and total land size allotted to each crop during the meher 2002, 2004 and 2007. Only 2\% of the plots cultivated were used to cultivale several crops at once. Hence multicropping is not of a particular cncern here. Each row of the table presents the result for one particular outcome. Significance levels are denoted as follows: ${ }^{*} \mathrm{p}<0.10,{ }^{* *}$ $\mathrm{p}<0.05,{ }^{* * *} \mathrm{p}<0.01$.

In columns (1), (3) and (5) I report the average level of the outcome as measured amoung the households with a land certificate by June 2006 at each round of the survey. Likewise, columns (2), (4) and (6) show estimates of the ATT using the estimator of Equation (10) in 2002, 2004 and 2007. The propensity score used to estimate the ATT is approximated using a 1 degree polynomial series. The standard errors are computed as described in Abadie (2005).

\footnotetext{
${ }^{\dagger}$ Indicates a binary variable.
} 


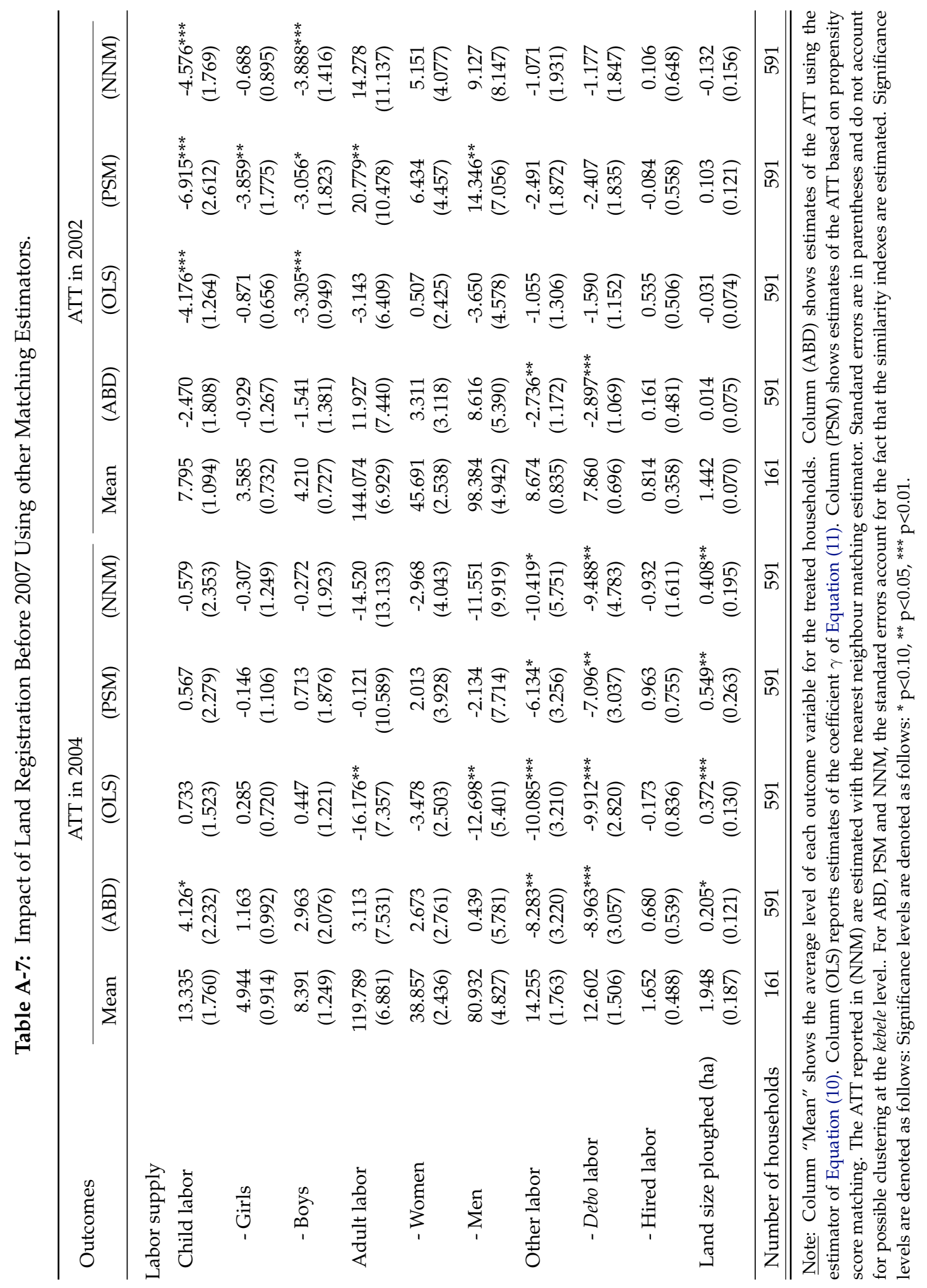


Table A-8: Impact of Land Certificate on the Treated Excluding Households in Wolkie.

\begin{tabular}{|c|c|c|c|c|c|c|}
\hline \multirow{2}{*}{ Outcomes } & \multicolumn{2}{|c|}{ ATT in 2007} & \multicolumn{2}{|c|}{ ATT in 2004} & \multicolumn{2}{|c|}{ ATT in 2002} \\
\hline & Mean & ATT & Mean & ATT & Mean & ATT \\
\hline \multicolumn{7}{|c|}{ Labour supply is measured in person-day } \\
\hline \multirow[t]{2}{*}{ - Male children } & 10.832 & $1.527^{*}$ & 8.391 & 0.519 & 4.210 & 0.324 \\
\hline & $(1.479)$ & $(0.835)$ & $(1.249)$ & $(0.882)$ & $(0.727)$ & $(0.775)$ \\
\hline \multirow[t]{2}{*}{ - Male adults } & 88.686 & $-8.527^{* * *}$ & 80.932 & -2.068 & 98.384 & 0.334 \\
\hline & $(5.142)$ & $(3.060)$ & $(4.827)$ & $(2.838)$ & $(4.942)$ & $(2.768)$ \\
\hline \multirow[t]{2}{*}{ - Hired workers } & 1.342 & $0.059^{*}$ & 1.652 & 0.138 & 0.814 & 0.084 \\
\hline & $(0.280)$ & $(0.034)$ & $(0.488)$ & $(0.106)$ & $(0.358)$ & $(0.142)$ \\
\hline \multirow[t]{2}{*}{ Land size ploughed (ha) } & 2.191 & 0.247 & 1.948 & $0.220^{*}$ & 1.442 & 0.056 \\
\hline & $(0.125)$ & $(0.161)$ & $(0.187)$ & $(0.124)$ & $(0.070)$ & $(0.106)$ \\
\hline Number of households & 161 & 502 & 161 & 502 & 161 & 502 \\
\hline
\end{tabular}

Note: The table shows the ATT of land certificates when households from Wolkie are excluded from the sample. Since land registration activities were still ongoing in Wolkie at the time of the meher 2006-07, the untreated households living there have likely increased their labour supply to signal land use. The ATT are estimated with the semi-parametric difference-in-difference estimator. Standard errors are in parentheses and significance levels are denoted as follows: ${ }^{*} \mathrm{p}<0.10,{ }^{* *} \mathrm{p}<0.05,{ }^{* * *} \mathrm{p}<0.01$. 